\title{
A review of vegetation-atmosphere interactions and their influences on mesoscale phenomena
}

\author{
Renee A. McPherson*
}

\author{
Oklahoma Climatological Survey, University of Oklahoma, 120 David L. Boren \\ Boulevard, Suite 2900, Norman, OK 73072-7305, USA
}

\begin{abstract}
Vegetation strongly influences exchanges of energy and moisture between land and atmosphere through (1) the vegetation's response to incoming radiation and its emission of longwave radiation (2) the vegetation's physical presence, and (3) the plant's transpiration. These processes affect the diurnal temperature range, processes in the atmospheric boundary layer, cloud cover, rainfall, differential heating, and atmospheric circulations. This paper overviews how vegetation interacts with surface energy and moisture budgets and reviews both observational and modelling studies that examine how vegetation affects weather and climate on the mesoscale (ie, phenomena 10 s to 100 s of kilometres in horizontal size).
\end{abstract}

Key words: land-air interaction, mesoscale processes, regional climatology, vegetation, vegetation-atmosphere interaction.

\section{Introduction}

The quantity, type, and condition of vegetative ground cover and canopy plants strongly influence the exchanges of energy and moisture between Earth's surface and the adjacent atmosphere (Taylor and Lebel, 1998). Plants also intercept water during rainfall and provide a surface on which dew or frost may form. Vegetation may drip water to the ground and evaporate water directly to the atmosphere, and it regulates net incoming radiation via albedo differences, absorption of short- and long-wave radiation, and emission of longwave radiation (Segal et al., 1988; Lakhtakia and Warner, 1994).
Past studies indicate that an increase in living vegetation coverage (the percentage of a given area covered by vegetation) across a region increases the following physical variables: albedo for near-infrared wavelengths, absorption of solar radiation, roughness length, turbulence, evapotranspiration, relative and specific humidities, equivalent potential temperature, moisture retention, and minimum temperatures (Anthes, 1984). In addition, an increase in coverage decreases the following variables: albedo for visible wavelengths, infrared emission, surface winds, runoff and erosion, Bowen ratio, and maximum temperatures (Anthes, 1984). There also is evidence that an increase in

\footnotetext{
*Email: renee@ou.edu
} 
vegetation may increase clouds, rainfall, and upward motion (Schickedanz, 1976; Freedman et al., 2001).

Senescent, irrigated, grazed, and dead vegetation may reinforce, negate, or have no impact on the physical properties and processes mentioned above (Otterman, 1976; 1981; Turner et al., 1992; Walthall and Middleton, 1992; Schwartz, 1992; Adegoke et al., 2003). Indeed, even the type of vegetation causes different impacts, including the generation of different transpiration rates (Carleton et al., 1994; Segal et al., 1988; Doran et al., 1992; Bonan, 2001).

\section{Mechanisms of vegetation- atmosphere interactions}

The primary physical attributes of plants that cause interactions with the atmosphere are (1) the vegetation's response to incoming radiation and its emission of longwave radiation (2) the vegetation's physical presence, which relates to its roughness length (3) the plant's transpiration, which regulates the latent heat flux portion of the surface energy budget, and (4) the plant's photosynthesis, which generates $\mathrm{CO}_{2}$. This review focuses on effects of vegetation on surface energy and moisture exchanges; hence, $\mathrm{CO}_{2}$ flux will not be discussed further.

\section{Radiative effects}

Through the plant's albedo, vegetation coverage modifies net incoming solar radiation - the source for surface energy exchanges (Figure 1). The partitioning of incident radiant energy into reflected, scattered, transmitted, or absorbed radiation depends on leaf, plant, and substrate characteristics, including variations in vegetation type, structure, coverage, and condition (Matthews and Rossow, 1987). A host of field experiments has been conducted to better understand the interactions between radiation and plants.

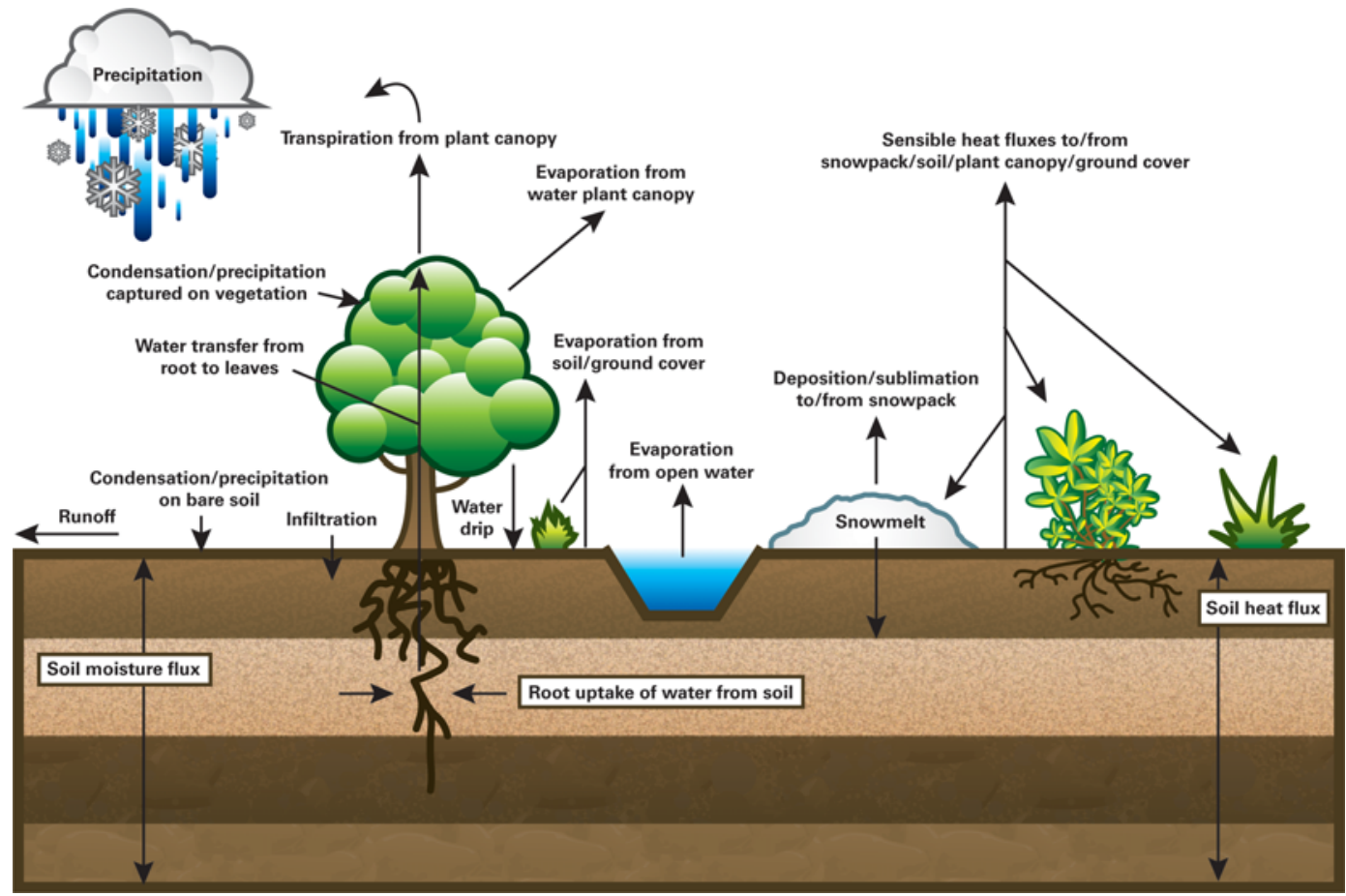

Figure 1 Schematic of shortwave and longwave radiation interactions with the land-air-vegetation system (IR = infrared radiation) 
Using three native grasses from the study region of the First International Satellite Land Surface Climatology Project (ISLSCP) Field Experiment (FIFE), Walter-Shea et al. (1992) determined that healthy green grass reflected and transmitted weakly in the visible and strongly in the near infrared. These results were attributed to physical properties of the plant. Pigments in a healthy green leaf absorbed strongly in the visible. Conversely, the leaf mesophyll scattered most of the incident nearinfrared radiation (NIR). In addition, optical properties of leaves caused attenuation in the middle infrared band when the water content of leaves increased. Mild water stress decreased the turgor pressure in the cell and created a decrease in the cell volume and intercellular space.

In an analysis of surface reflectance from visible wavelengths, Matthews and Rossow (1987) resolved that the primary factor controlling surface reflectance at $0.6 \mu \mathrm{m}$ was the density of vegetation cover. Because vegetation appeared darker at this wavelength than most soils, a stratification of reflectance values was evident from dense forest to steppe or from grassland to desert. The spectral variation within forests, either locally or between ecosystems, was less than that within shrubs or grasslands.

Matthews and Rossow (1987) also ascertained that snowcover amplified the stratification of reflectance values over vegetation. This conclusion was supported by Betts and Ball (1997), who examined the annual cycle of albedo over grassland, aspen forest, and coniferous forest using data from the Boreal Ecosystem-Atmosphere Study (BOREAS) in Saskatchewan and Manitoba, Canada. During the summer, without snowcover, daily average albedos were approximately 0.2 over grass, 0.15 over aspen forest, and 0.083 over coniferous forest. During the winter, with snow on the ground or in the canopy, analogous values were 0.75 for grasses, 0.21 for aspens, and 0.13 for conifers.

Ba et al. (2001) documented differences in the albedo-vegetation relationship between wet and dry regions. Monthly albedos calculated from Meteosat satellite data over Africa during 1983-88 were compared to values of the normalized difference vegetation index (NDVI). $(\mathrm{NDVI}=(N I R-$ red $) /(N I R+$ red $)$, where NIR is the amount of energy measured in the near-infrared spectral band and red is the amount of energy measured in the red portion of the spectrum.) Over wetter regions, there was a relatively small range of albedos (from 0.10 to 0.20 ) yet a large range of NDVI values (0.1 to 0.5$)$ and an evident seasonal cycle of albedo. Over drier regions, there was a larger range of albedos (from 0.10 to 0.35 ), a similar range of NDVI values (0.1 to 0.5$)$, but little evidence of a seasonal cycle of albedo. The authors hypothesized that vegetation in wet regions adequately concealed the soil; hence, seasonal changes in foliage (and the corresponding changes in NDVI values) did not impact albedo considerably. In dry regions, however, where vegetation was sparse and bare soil was exposed, the soil moisture influenced the albedo significantly.

Changes in the radiative effects of vegetation occur as plants mature during their growing season. Turner et al. (1992) discovered that, across all wavelength bands except NIR, reflectance values from tallgrass canopies increased as the plants matured and senescent material increased. Walthall and Middleton (1992) documented that, after senescence commenced, leaf pigments began to absorb more strongly in the blue region than in the red region of the visible spectrum. The sensitivity of the red and blue spectral bands appeared to be related to alterations in vegetative pigment concentrations. As the plant matured, chlorophylls dominated; by senescence, carotenoids dominated.

Moore et al. (1996) examined the growing season cycle of albedo in a deciduous forest canopy at the Environmental Monitoring Site in Harvard Forest. They detected forest canopy leaf-out and leaf-drop from an increase and decrease, respectively, of the global albedo. After the albedo initially increased at leaf-out, an $11 \%$ decrease in global albedo was recorded 
during the growing season; the albedo decrease principally resulted from a significant decrease of near-infrared reflectance. The decreasing values of NIR reflectance were attributed to phenological changes in the canopy, including water stress, a change in thickness of the mesophyll layer, or a change in the canopy structure (eg, leaf-area density or leaf-angle distribution).

Otterman (1981) demonstrated the effect of both living and dead vegetation on radiation absorption. Albedos computed using Landsat images of naturally vegetated land in the SinaiNegev, Afghanistan-USSR, and the Sahel were compared to those from nearby anthropogenically modified regions. The data indicated that the albedo over the protected land was significantly lower (by almost 0.2 ) than that over the modified land. Consequently, native plants increased their absorption of solar radiation. Moreover, absorption was higher in both the visible and infrared even though the living vegetation had a high albedo in the infrared. This result led Otterman (1981) to conclude that, because of its low albedo in the infrared, dead plant matter (underlying the living vegetation) in the protected area increased the total energy absorption of the region. Similarly, Otterman (1976) determined that the significant emission of infrared radiation by forest debris resulted in warmer surface temperatures over densely vegetated areas as compared to nearby sparsely vegetated regions.

Field management practices that modify the density of vegetation also have been shown to change the reflective characteristics of the surface, thus affecting the surface energy budget. During FIFE in 1987, Turner et al. (1992) studied reflectance values over grassland at the Konza Prairie Research Natural Area. Radiation measurements were compared among sites characterized by these grassland field management practices: mowed, grazed, burned and grazed, burned and ungrazed, and natural (unmanaged). During the growing season, shortwave reflectance averaged about $8 \%$ higher on grazed sites than on burned, ungrazed sites; it ranged from $4 \%$ to $27 \%$ higher on mowed sites than on unmowed control plots. Near-infrared reflectance averaged about 15\% lower on grazed sites than on burned plots and 18\% lower on mowed sites than on unmowed plots. Because of the soil's higher albedo in the visible and lower albedo in the near-infrared, defoliation severe enough to expose the soil tended to increase reflectance of visible light and decrease reflectance of NIR.

\section{Roughness length}

As objects extend farther above the surface, the roughness length increases. The structure of most plants extends above the ground from a few centimetres for short ground covers to tens of metres for tall trees. The heightened roughness length associated with vegetation (contrasted with bare soil) weakens nearsurface wind speeds and intensifies low-level turbulence (Anthes, 1984; Lee, 1992). On the small scale, this enhanced low-level turbulence may accelerate the initiation of convection (Garrett, 1982); on the synoptic scale, frictional inflow into extratropical cyclones may increase, possibly resulting in enhanced precipitation.

Doran et al. (1995) attributed differences in the roughness length to causing weaker $9 \mathrm{~m}$ winds over cropland than over steppe. During a field experiment in Washington early in June 1992, these researchers observed winds over the farm (roughness length $\sim 0.1 \mathrm{~m}$ ) to be weaker than winds over the steppe (roughness length $\sim 0.02 \mathrm{~m}$ ) on all days. Similarly, Rosenan (1963) observed an increase in autumn precipitation near Tel Aviv, Israel, following irrigation of nearby land. Rosenan hypothesized that the taller, irrigated vegetation had increased the surface roughness length and associated turbulent mixing, resulting in more convection.

Bechtold et al. (1991) used a two-dimensional version of the meso- $\beta$ model of Nickerson et al. (1986) to examine, in part, the impact of vegetation on turbulent mixing. In a simulation that compared the turbulent activity 
over adjacent areas of bare land and ocean, significant turbulence developed over land but little or none occurred over the water. To determine if the lack of turbulence over water simply resulted from stability associated with the cool water surface, the authors also ran a simulation with contiguous areas of transpiring crop and forest. Results indicated that turbulent mixing occurred over both the cropland and the forest, with vertical mixing predominant over the forest. The authors attributed the presence of turbulence over both foliages to the roughness lengths of the vegetation.

\section{Latent and sensible heat fluxes}

Transpiration, regulated by the aperture of plant stomata, governs the partitioning of radiant energy absorbed by vegetation (Figure 2). When vegetation is unstressed, stomata open and the plant transpires freely. Large latent heat fluxes can result from abundant insolation. When vegetation is stressed, the stomata close and transpiration stops. As a result, abundant insolation is converted mostly to sensible heat flux (Avissar and Pielke, 1989; Chen and Avissar, 1994). Hence, the Bowen ratio (ie, ratio of sensible heat flux to latent heat flux at the surface) is a good indicator of both environmental stress at the surface and the condition of the vegetation. Bowen ratio values range from infinity in extremely dry conditions to near zero over wet regions. Negative values can occur over strongly transpiring vegetation for certain atmospheric conditions (Avissar and Pielke, 1989).

Observations from warm season crops indicate that more than $70 \%$ of the net radiation can be converted to latent heat flux, leaving less than $30 \%$ available for sensible heat flux (Segal et al., 1988). For example, Aase and

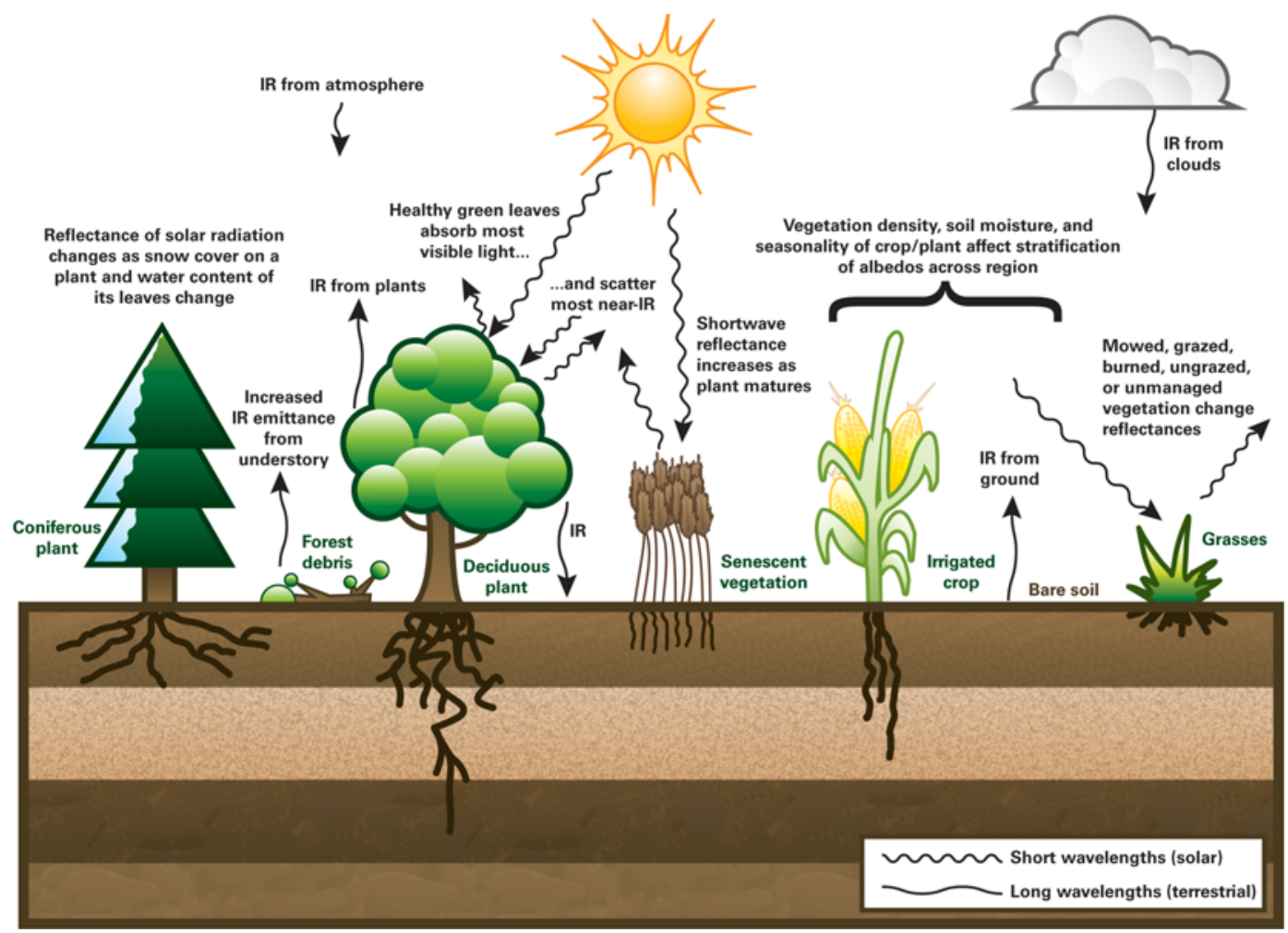

Figure 2 Schematic of latent and sensible heat fluxes that affect the land-airvegetation system 
Siddoway (1982) measured evapotranspiration over wheat in a semi-arid region near Sidney, MT, during two growing seasons: (1) 4 April to 16 August 1978 and (2) 5 May to 17 August 1979. The average evapotranspiration rate was $4.7 \mathrm{~mm}$ day $^{-1}$ and $5.5 \mathrm{~mm}$ day $^{-1}$ for the 1978 and 1979 warm seasons, respectively. Given approximated values of net radiation for this location and dates, Segal et al. (1988) determined that, if the net radiation were converted entirely into evaporation, these rates would have been 6.0 and $6.2 \mathrm{~mm}$ day $^{-1}$, respectively. Hence, between $78 \%$ and $89 \%$ of the available energy was partitioned into latent heat flux by the wheat.

From 20 June to 17 August 1979, Aase and Siddoway (1982) measured evapotranspiration over both wheat and nearby bare soil and discovered rates of 4.5 and $0.9 \mathrm{~mm} \mathrm{day}^{-1}$, respectively. In other studies (Rogerson, 1976; Reddy, 1983), an examination of observations likewise indicated that the typical evapotranspiration rate over wheat was at least $2 \mathrm{~mm}$ day $^{-1}$ higher than that over bare soil. In contrast, the evapotranspiration from forest canopies was found to be $1-2 \mathrm{~mm}^{\text {day }}{ }^{-1}$ less than that over well-irrigated crops (Segal et al., 1988). Values of latent heat flux also were lower for non-irrigated crops than for irrigated crops.

Doran et al. (1992) documented results from a regional flux field campaign near Boardman, OR, during early June 1991. Using both surface and aircraft measurements, sensible and latent heat fluxes were compared between steppe, shrub, grass, and irrigated crops of wheat, alfalfa, corn, and potatoes during a span when almost no rainfall occurred. The average daily maxima of latent heat flux for the shrub and grass sites ranged between 45 and $80 \mathrm{~W} \mathrm{~m}^{-2}$, those over the steppe were around $50 \mathrm{~W} \mathrm{~m}^{-2}$, and those over irrigated cropland were between 350 and $425 \mathrm{~W}$ $\mathrm{m}^{-2}$. Flying between 12 and $14 \mathrm{~m}$ above ground level over the steppe and irrigated cropland on 15 June, aircraft measured minimal fluctuations in mixing ratios over the steppe but significant fluctuations in mixing ratios over the farm. Mixing ratios were $0.4 \mathrm{~g} \mathrm{~kg}^{-1}$ higher over the farm than over the steppe. On the same day, air temperatures and temperature fluctuations were larger over the steppe than over the farmland, indicating that sensible heat flux was enhanced over the steppe relative to the crops.

Results from similar experiments the following year were reported in Doran et al. (1995). On a mid-June day, when winds ranged from 3 to $7 \mathrm{~m} \mathrm{~s}^{-1}$, surface fluxes of sensible heat over the steppe peaked at $300 \mathrm{~W} \mathrm{~m}^{-2}$ or more while those over the farm were $80 \mathrm{~W} \mathrm{~m}^{-2}$ or less. Latent heat fluxes over the steppe averaged less than $100 \mathrm{~W} \mathrm{~m}^{-2}$ whereas those over the farm ranged from 400 to $500 \mathrm{~W} \mathrm{~m}^{-2}$. On another day, when winds ranged from 4 to $11 \mathrm{~m}$ $\mathrm{s}^{-1}$, latent heat fluxes over the crops reached values greater than $700 \mathrm{~W} \mathrm{~m}^{-2}$. During windy days, latent heat fluxes over both land use types increased while sensible heat fluxes slightly increased over the steppe and decreased over the farm.

The development of the plant itself influences latent heat fluxes. Moore et al. (1996) measured the Bowen ratio over a deciduous forest canopy during a growth cycle. After leaves first emerged, transpiration slowly increased. As leaves matured fully, transpiration increased substantially until midsummer, when it reached a plateau (see also Fitzjarrald et al., 2001; Yi et al., 2001). During August, however, transpiration began to decline, as woody tissue became more prevalent. Measurements of latent heat flux above the canopy and in the subcanopy (understorey) mirrored these changes. During winter, the subcanopy accounted for almost all of the above-canopy water vapour flux. By midsummer, the subcanopy evapotranspiration accounted for only about $10 \%$ of the above-canopy flux of water vapour. The sensible heat flux in the subcanopy was maximized during the spring and fall, when the canopy was leafless and insolation was greater compared to winter.

Vegetation density alters the distribution of surface heat fluxes across a region. Smith et al. (1994) examined surface fluxes across 
tallgrass prairie using data from the fifth FIFE intensive field campaign (23 July to 12 August 1989). During the period studied, a northwestto-southeast foliage gradient was observed across the Konza Prairie, with greener and more dense vegetation located in the southeast (SE) quadrant. Rainfall received within the SE quadrant was twice that measured within the other three quadrants, thus enhancing the vegetation gradient throughout the study period. Although net radiation was nearly constant across all quadrants, the SE quadrant was characterized by higher latent heat fluxes and lower sensible heat fluxes during the day than the other quadrants. Values of latent flux in the SE quadrant were more than twice those for the northwest quadrant.

As discussed earlier, net radiation measured above the canopy differs among plant types; hence, the amount of energy available for transpiration and the magnitude of transpiration differ among plant types. Using preliminary data from field experiments on 10 May 1997 and 20 May 1997 obtained via the Cooperative Atmosphere Surface Exchange Study (CASES; hereafter referred to as CASES-97), LeMone et al. (2000) documented relationships between surface fluxes and vegetation type (Figure 3 ) on days with weak surface winds (5-6 $\mathrm{m} \mathrm{s}^{-1}$ from the southsouthwest on 10 May, and 6-7 $\mathrm{m} \mathrm{s}^{-1}$ from the east to east-northeast on 20 May). Soil moisture values were greater and more uniform on 20 May than on 10 May because of a recent, widespread rainfall event. Three types of surface coverage were compared: growing winter wheat, short grass prairie, and bare soil. Data from CASES-97 indicated that, as a result of evapotranspiration, the latent heat flux (LE) was greater than the sensible heat flux $(\mathrm{H})$ on both days over the growing winter wheat. In contrast, $L E \approx H$ over the grassland and $\mathrm{LE}<\mathrm{H}$ over the bare soil on 10 May. On 20 May, however, LE $>\mathrm{H}$ above all three coverage regimes and, significantly, LE was fairly uniform across the coverages. The authors hypothesized that this uniformity resulted from three separate effects: (1) substantial evaporation from wet soil at the bare soil site (2) enhanced evapotranspiration from greener grassland, and (3) reduced evapotranspiration from wheat reaching maturity and becoming senescent.

Analyses of CASES-97 data disclosed other contrasts between variables measured across different vegetative regimes (LeMone et al., 2000). Throughout the day on both 10 and 20 May, values of soil heat flux were largest at the bare ground site and smallest at the grassland site. Sensible heat fluxes were lower and more uniform on 20 May, the day with wetter surfaces. On 10 May, the drier day, larger values of sensible heat flux were associated with lower values of NDVI (ie, less green vegetation) and with a decreased downward $\mathrm{CO}_{2}$ flux (ie, less photosynthesis). In addition, infrared radiometric surface temperatures were cooler, warmed more slowly, and heated more uniformly on 20 May than on 10 May. Temperatures at $2 \mathrm{~m}$, however, warmed more rapidly on 20 May than on 10 May, presumably because the boundary layer was shallower on 20 May. Thus, the heating was constrained within a shallower layer. On 10 May, the daytime mixing ratio (between 1000 and 1800 CST) was $1.5 \mathrm{~g} \mathrm{~kg}^{-1}$ larger over winter wheat than over either grassland or bare soil.

Yates et al. (2001) used data from the full CASES-97 field experiment - ranging from 21 April to 22 May 1997 - to determine additional information about fluxes over varying land covers. First, the authors noted that cloud cover increased the variability of latent heat flux more at sites with growing winter wheat than at sites with grassland or pasture. In contrast, cloud cover did little to change the variability of sensible heat flux over either vegetation type. Second, on clear days, mean latent heat fluxes, based on 6-h averages centred at solar noon, were about $300 \mathrm{~W} \mathrm{~m}^{-2}$ over winter wheat, $210 \mathrm{~W} \mathrm{~m}^{-2}$ over grassland/pasture, and about $180 \mathrm{~W} \mathrm{~m}^{-2}$ over bare soil/sparse vegetation. Using these same days, the mean sensible heat flux averaged $250 \mathrm{~W}$ $\mathrm{m}^{-2}, 180 \mathrm{~W} \mathrm{~m}^{-2}$, and $160 \mathrm{~W} \mathrm{~m}^{-2}$ over wheat, grassland, and sparse vegetation, respectively. 

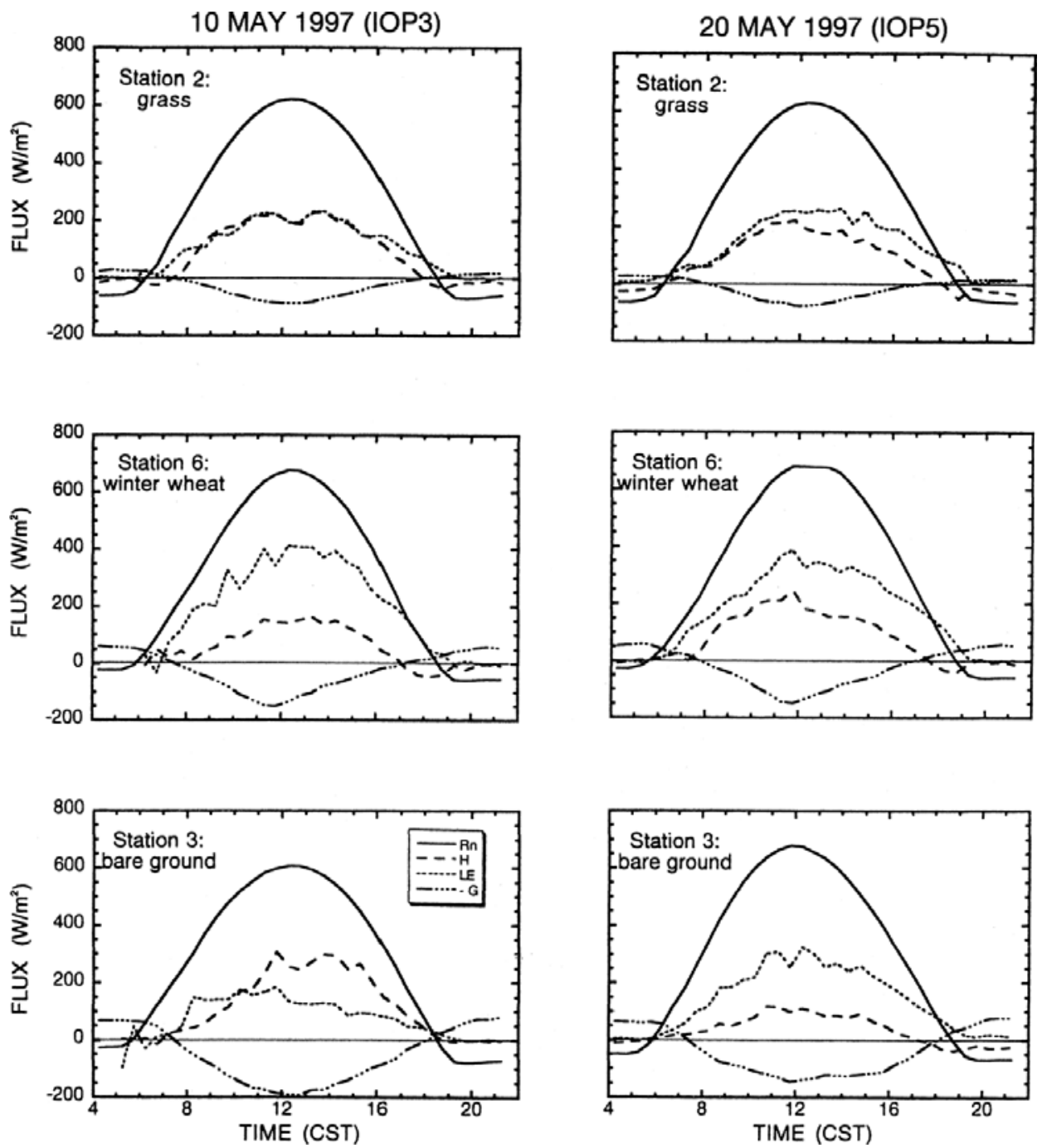

Figure 3 The surface energy budget for three stations for 10 May 1997 (left) and 20 May 1997 (right) using data intensive observing periods (IOP) of the Cooperative Atmosphere Surface Exchange Study. Station 2 (top) was a grassland station at the highest elevation for the observing sites; station 6 (middle) was a river-bottom site with winter wheat; and station 3 was a bare-ground river-bottom site. The plots show components of the surface energy budget $\left(R_{n}=H+L E+G\right)$, where $R_{n}$ is the net radiation, $H$ is the sensible heat flux, LE is the latent heat flux, and $G$ is the heat flux into the ground. In this case, $-\mathrm{G}$ is plotted to distinguish its values from those of $\mathrm{H}$ and $\mathrm{LE}$ Source: LeMone et al. (2000); courtesy of the American Meteorological Society. 
Third, data from clear days also established that latent heat fluxes increased over the grassland throughout the course of the field experiment, as grass green-up occurred and the vegetation gradually became more photosynthetically active.

Clark and Arritt (1995) used the onedimensional primitive equation model by Heim (1993) and Segal et al. (1995) to examine the effects of vegetation and soil moisture on the development of deep convection. The authors conducted 54 independent simulations out to 12 hours. The parameter space spanned from 0.075 to 0.450 for volumetric soil moisture content and from 0 to $100 \%$ for vegetation coverage. Using a representative midsummer sounding from Topeka, KS, Clark and Arritt (1995) ascertained that sensible heat flux decreased with increasing foliage for relatively dry soils and was relatively constant or slightly increased with increasing foliage for saturated soils. In particular, at solar noon, the sensible heat flux was $430 \mathrm{~W} \mathrm{~m}^{-2}$ over dry, bare soil but was only about $100 \mathrm{~W} \mathrm{~m}^{-2}$ over saturated bare soil. Above the fully vegetated surface, values of sensible heat flux ranged from $270 \mathrm{~W} \mathrm{~m}^{-2}$ for dry soil to $130 \mathrm{~W} \mathrm{~m}^{-2}$ for saturated soil. In these same experiments, at solar noon, the latent heat flux was $90 \mathrm{~W}$ $\mathrm{m}^{-2}$ over dry, bare soil and $450 \mathrm{~W} \mathrm{~m}^{-2}$ over saturated, bare ground. Over the fully vegetated surface, values of latent heat flux ranged from $450 \mathrm{~W} \mathrm{~m}^{-2}$ for dry soil to $\sim 600 \mathrm{~W} \mathrm{~m}^{-2}$ for saturated soil. Hence, vegetation moderated the impact of variations in soil moisture.

\section{The mesoscale impact of vegetation}

For vegetation to influence weather or climate on the mesoscale (ie, 10s to 100s of kilometres in horizontal size), it must be of sufficient density and extent to alter significantly the partitioning of net radiation across a region. As a result, the atmospheric boundary layer and the free atmosphere above can be changed in a measurable way, including the diurnal temperature range, cloud cover, rainfall, heating patterns, or circulations.
1 Impact on the diurnal temperature range Using daily maximum and minimum temperature data from the US Historical Climatology Network (Easterling et al., 1996), Bonan (2001) created a monthly climatology of diurnal temperature range across the Midwest and Northeast United States for the period 1986-95. Land cover across the Midwest was characterized by cropland; that of the Northeast was characterized by deciduous forests. Linear correlations between monthly diurnal temperature range and longitude denoted that the former increased with eastward longitude during May, June, and July. No correlation between diurnal temperature range and longitude existed during August.

These results were contrary to those expected from a documented eastward increase in cloud cover during those four months (Dai et al., 1997). If cloud cover were the predominant cause of a longitudinal change in temperature, then the longitudinal decrease of the maximum temperature should exceed that of the minimum temperature (Figure 4). Bonan (2001), however, observed the opposite: the minimum temperature cooled at a greater rate toward the east than did the maximum temperature. These results were consistent with a moderation of maximum temperatures by the Midwestern cropland as compared with the forested Northeast.

Durre and Wallace (2001) applied daily climatologies from the National Climatic Data Center (1999) to examine the diurnal temperature range for the eastern United States. As a result of an increase in both the length of the day and the daily net incoming solar radiation, the authors expected that the largest diurnal range of temperatures would occur around the summer solstice. Instead, they documented a seasonal minimum in the diurnal temperature range during the summer growing season. This summer minimum was more prominent when only clear days were considered, leading the authors to exclude seasonal changes in cloud coverage as the causal ingredient. In addition, the amplitude and seasonal length of the minimum were greater for 


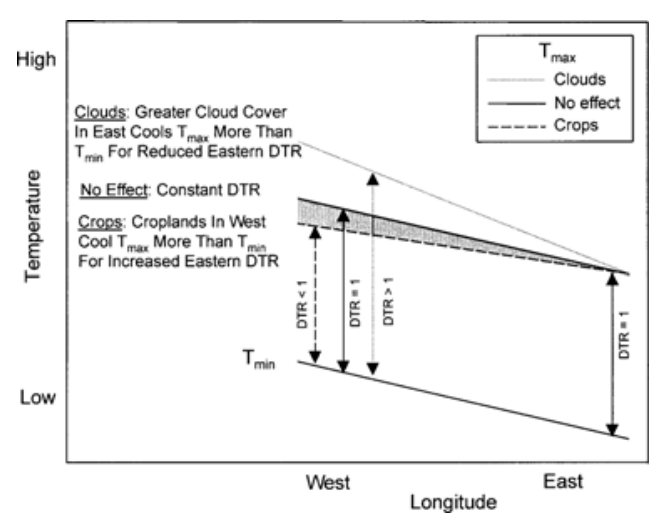

Figure 4 Observed west-to-east trends in maximum daily temperature ( $\mathrm{T}_{\text {max }}$; dashed line) relative to minimum daily temperature $\left(T_{\min }\right)$ as compared to expected trends of (1) a constant daily temperature range (DTR, where $\mathrm{DTR}=\mathrm{T}_{\max }-\mathrm{T}_{\min }$; solid line) and (2) a reduction in DTR from an eastward increase in cloud cover (dotted line). The vertical arrows display the magnitude of DTR relative to the constant DTR. The shaded region represents the minimal cooling associated with croplands in the Midwest

Source: Bonan (2001); courtesy of the American Meteorological Society.

southern latitudes than for northern latitudes (Figure 5). These observations were congruent with a lengthening of the growing season from north to south. Finally, a comparison of diurnal temperature range with weekly NDVI demonstrated that the maximum in the former occurred only one to two weeks after the onset of a rapid increase in weekly NDVI values. As vegetation rapidly matured, the diurnal temperature range decreased.

\section{Impact on the boundary layer}

In numerical studies, the depth of the planetary boundary layer (PBL) was shallowest over an irrigated area of vegetation and deepest over dry, bare land (Segal et al., 1989). Hence, the mixing ratio throughout the PBL was largest over vegetated surfaces, where evapotranspiration was enhanced, dry air entrainment was reduced, and air was mixed within a shallower layer (Segal et al., 1995). As a result, given a vertical profile of temperature and moisture that already was favourable for thunderstorms, growing vegetation could greatly enhance the development of convective clouds. An initially stable environment would reduce turbulence and thus support a gradual increase in moist

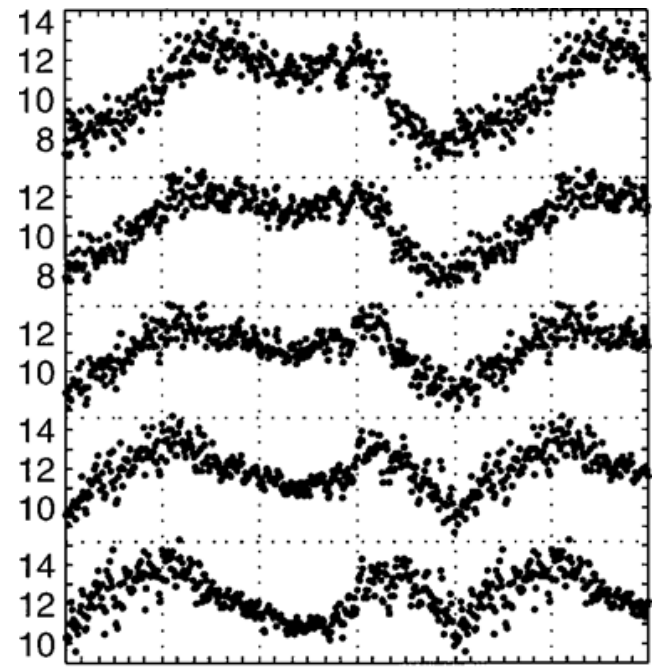

J FMAM J J A SOND J FMAM J

Figure 5 Climatology of the diurnal temperature range $\left(\mathrm{DTR} ;{ }^{\circ} \mathrm{C}\right)$ across the eastern United States, between $80^{\circ}$ and $90^{\circ} \mathrm{W}$. From top to bottom, the plots are $2.5^{\circ}$ latitude bands centred at $42.5^{\circ}, 40^{\circ}, 37.5^{\circ}, 35^{\circ}$, and $32.5^{\circ} \mathrm{N}$. Each dot represents the average DTR from 1966 to 1995 for one day of the year. One-and-a-half annual cycles are displayed. The plots display a seasonal minimum in the DTR during the summer growing season Source: Durre and Wallace (2001); courtesy of the American Meteorological Society. 
static energy over vegetation. Although convection might initiate later, clouds could persist longer within this initially stable environment than within initially neutral or unstable environments (Hong et al., 1995).

Because upwind conditions may influence measurements at a given location, the PBL over vegetation must be examined relative to its nearby environment. For example, on days when winds blew perpendicular to a land-use boundary between steppe and farmland, Doran et al. (1995) noted that growth of the mixed layer over the farm was modified considerably by the surface flux of sensible heat over the steppe. Conceptually, the authors determined that the air was heated over the steppe and advected over the farm, where it became part of the boundary layer structure. As a result, the mixed layer depth was comparable between steppe and farm. Because strong surface heating ceased when the air moved over the irrigated crops, temperatures of the mixed layer generally were about $1^{\circ} \mathrm{C}$ cooler over the farm than over the steppe. A simple thermodynamic model confirmed that the advection of the mixed layer from above the steppe to over the farmland could account for the PBL observations over the farm.

McPherson and Stensrud (2005) used the Fifth-generation National Center for Atmospheric Research - Pennsylvania State University mesoscale model (Anthes and Warner, 1978; Grell et al., 1994) to compare model runs that were initiated identically but incorporated different land uses (ie, anthropogenically modified or natural coverage) over a wheat belt defined across the US Southern Great Plains. Numerical model results generally agreed with observations across Oklahoma's wheat belt for the case studies of 27 March 2000 and 5 April 2000 (McPherson et al., 2004). The impacts of the mesoscale belt of growing wheat included increased values of latent heat flux and decreased values of sensible heat flux over the wheat, increased values of atmospheric moisture near the surface above and downstream of the wheat, and a shallower PBL above and downstream of the wheat. In the sheared environments that were examined, a shallower PBL that resulted from growing wheat (rather than natural vegetation) led to reduced entrainment of higher momentum air into the PBL and, thus, weaker winds within the PBL over and downwind from the growing wheat (Figure 6).

\section{Impact on clouds}

Observational evidence suggests that, during fair weather, vegetation modifies the development of cumulus clouds. Cutrim et al. (1995) examined the impact of deforestation on cumulus cloud fields across parts of Amazonia during the end of the dry season (July through October). Using visible satellite images at 1800 UTC, the authors detected imprints of land-surface features, including rivers, a natural savanna, and a deforested region. The latter two features were indicated by denser fields of cumulus. Similarly, Carleton et al. (1994) and Nair et al. (2003) documented increases in convective clouds over forested areas as compared to cropland or pastures.

Rabin et al. (1990) observed that clouds first initiated over a region of harvested wheat that was adjacent to growing vegetation; clouds were suppressed over forested areas. The authors conducted their observational study during late June 1988 - after the wheat harvest reduced vegetation across the Oklahoma wheat belt to stubble. This harvested area displayed albedos 10-20\% higher than the adjacent grassland or forest, and the absence of growing vegetation reduced the transport of soil moisture from root level into the atmosphere. As a result, the incoming solar energy was partitioned primarily into sensible heat flux, creating a region of locally warmer temperatures over the wheat belt during the daytime. In a dry environment, this surface heating (and its mixture through the PBL) caused the convective temperature to be attained about two hours earlier over the wheat stubble than over adjacent vegetated areas. Clouds were noticeably absent, on the other hand, at midday over areas with dense vegetation, such as forested regions to the east 
PBL Height - Difference Field

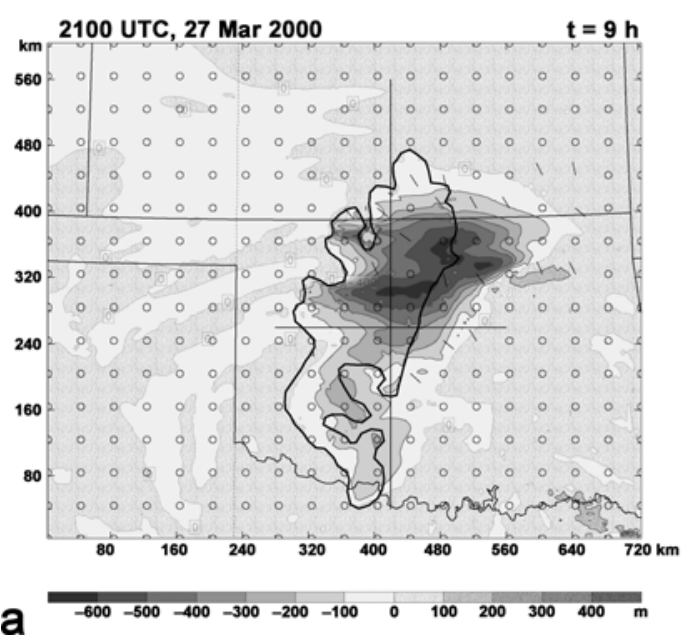

Wind at 1 km - Wheat Run

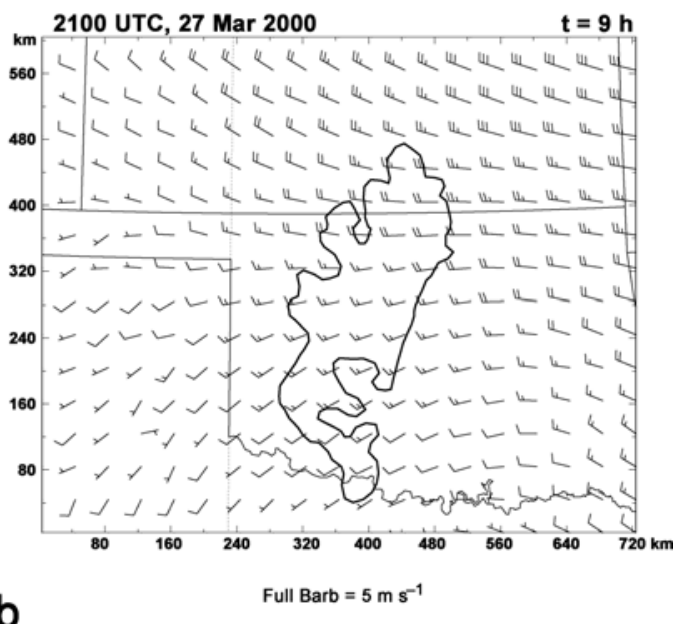

Figure 6 Results from simulations of 27 March 2000 conditions across Oklahoma during the peak of the winter wheat growing season. The black outline depicts the boundary of the winter wheat belt. Both a growing wheat crop and a natural grass cover were simulated. The left figure (a) depicts the difference field of the modelcalculated planetary boundary layer (PBL) heights (contours) and horizontal winds at $1 \mathrm{~km}$ (barbs) at 2100 UTC. Negative values (in solid greys) indicate PBL heights were lower for the wheat simulation than the natural vegetation run. Horizontal speed differences less than $1.25 \mathrm{~m} \mathrm{~s}^{-1}$ are displayed as open circles. The right figure (b) depicts the wind field (barbs) from the wheat run at $1 \mathrm{~km}$ above sea level for 2100 UTC. The shallower PBL that resulted from growing wheat (left figure) led to reduced entrainment of higher momentum air (right figure) into the PBL and, thus, weaker winds within the PBL over and downwind from the growing wheat Source: McPherson and Stensrud (2005); courtesy of the American Meteorological Society.

and southeast of Oklahoma City. Across those densely vegetated areas, as much as $70 \%$ of the insolation was partitioned into latent heat flux; thus, less energy remained for sensible heating and PBL warming.

The observational results of Rabin et al. (1990) were consistent with those modelled by Rabin (1977). Using a surface energy-budget model, Rabin (1977) documented that, when the lower atmosphere was relatively dry, less energy was required to form clouds over regions with high Bowen ratios; hence, convection first initiated over drier, hotter surfaces. When the lower atmosphere was relatively moist, less energy was required to form clouds over regions with low Bowen ratios; hence, convection first initiated downwind of moist surfaces. The conditions necessary to obtain these results were minimal topography, calm winds, landscape features of sufficient size to modify an air mass, and about $200 \times 10^{4} \mathrm{~J} \mathrm{~m}^{-2}$ of combined sensible and latent heat fluxes for use in modifying the air mass.

Freedman et al. (2001) used National Weather Service observations from the eastern USA, a boundary-layer cloud analysis, and a variety of atmospheric turbulence and trace gas measurements in Harvard Forest 
(in north-central Massachusetts) to study the impact of boundary layer cumulus on vegetation-atmosphere feedbacks. The region studied was predominantly temperate deciduous, broadleaf evergreen, and boreal forests. Results indicated that, across the eastern United States, the occurrence of boundary layer cumulus (BLcu) increased rapidly with the development of transpiring vegetation. As BLcu developed during the growing season, observations that the afternoon lifted condensation level (LCL), relative humidity, and mixed-layer height remained relatively constant from late spring through summer implied that a coupling of the vegetation and atmosphere occurred. In addition, after BLcu appeared, a measured increase of $\mathrm{CO}_{2}$ uptake (indicating increased photosynthesis) occurred along with lower values of evapotranspiration, maximum temperature, and vapour pressure deficit as compared to clear days. In other words, BLcu tended to ameliorate the abundant summer insolation and high surface temperatures, allowing plants to recover from the environmental stress.

Jarvis et al. (1985) determined that BLcu and forest developed a positive feedback. As clouds initially shaded direct sunlight from vegetation, diffuse radiation increased. Because diffuse radiation penetrated deeper into the forest canopy, enhanced photosynthesis and transpiration efficiency resulted. As evapotranspiration within the forest increased the low-level moisture, the vapour-pressure deficit diminished and facilitated the continued formation of BLcu. In turn, BLcu further reduced environmental stresses and thus promoted stomata to remain open, enhancing evapotranspiration. The authors suggested that the increased extent and density of eastern forests across the USA during the past century contributed to the documented increase in relative humidities and cloudiness across this region during that period.

Environmental stress can be imposed not only by the atmosphere, but also by the soil. In a modelling study, Garrett (1982) examined the onset of convection between two identical forested regimes, one with adequate soil moisture for transpiration and one without. The simulation that used insufficient soil moisture for transpiration exhibited higher surface temperatures, faster growth of the boundary layer, an earlier onset of convection, and an earlier end to rainfall than did the simulation that used adequate soil moisture. Other simulations indicated that denser vegetation served to increase transpiration, maintain cooler and more moist low-level air, reduce boundary layer depth and entrainment of dry air aloft, and decrease convective precipitation. (Because these simulations were conducted using a one-dimensional model, the impact of solenoidal circulations created by surface gradients was not considered.)

Hong et al. (1995) used the two-dimensional PBL model of Huang (1990) and Huang and Raman (1991a; 1991b) to investigate the effectiveness of vegetation to initiate clouds under different atmospheric stabilities. The experiments modelled two $80 \mathrm{~km}$ wide irrigated areas of vegetation that were located on opposing sides of an $80 \mathrm{~km}$ wide area of dry bare soil. Thermal contrasts that resulted from gradients in sensible heat flux across the different land surfaces caused model convection to develop. Numerical simulations indicated that, within a convectively unstable PBL, these convective clouds initiated earlier (ie, earlier existence of turbulence), dissipated sooner (ie, more vertical mixing that entrained dry air aloft), and had stronger vertical velocities than did clouds that developed within an absolutely stable atmosphere.

\section{Impact on rainfall}

Rain that falls onto vegetation affects the region for a longer period of time than that which falls onto bare land. Plants transport soil moisture from root depth to the leaves and evaporatively lose water through open stomata. The increased evapotranspiration decreases the vapour-pressure deficit, which, in turn, may enhance clouds and rainfall. The positive feedback that results can help the environment mitigate or recover from drought 
conditions. Observational and modelling studies indicate that regional-scale irrigation practices can alter convective rainfall patterns (Barnston and Schickedanz, 1984; Lanicci et al., 1987) and that forests may enhance convection and rainfall in the Tropics (Mahfouf et al., 1987; Segal and Arritt, 1992; Woodcock, 1992; Blyth et al., 1994; Trenberth, 1999).

Using the National Center for Atmospheric Research (NCAR) Community Climate Model, Hoffmann and Jackson (2000) studied the regional climatic effects of the conversion of tropical savanna to grassland. Model results indicated that this transformation caused significant declines in annual precipitation $(\sim 10 \%$ in four out of five regions), focused primarily during the transitional months between the wet and dry seasons (Figure 7). In addition, dry periods that lasted five days or more were more frequent during the wet season for the grassland simulations. The researchers attributed the overall decreases in precipitation equally to reductions in albedo (by 0.036) and roughness length (by $0.388 \mathrm{~m}$ ).

Simulations also have demonstrated that total rainfall increases as the vegetation density increases, regardless of the soil moisture content, and that rainfall maximizes over saturated, fully vegetated soil (Clark and Arritt, 1995). Mintz (1984) concluded that precipitation increased over land when evaporation increased. Clark and Arritt (1995) noted that, when using an average thermodynamic profile during the summer at Topeka, KS, convection occurred earlier and rainfall amounts increased as the foliage increased. Their model results did not vary even when moderate changes were applied to the initial moisture and temperature profiles. Garrett's (1982) simulations, however, provided contrasting results. Given an initial atmosphere with sufficient low-level moisture and in the absence of mesoscale circulations, Garrett concluded that soil evaporation and plant transpiration had negligible impacts on
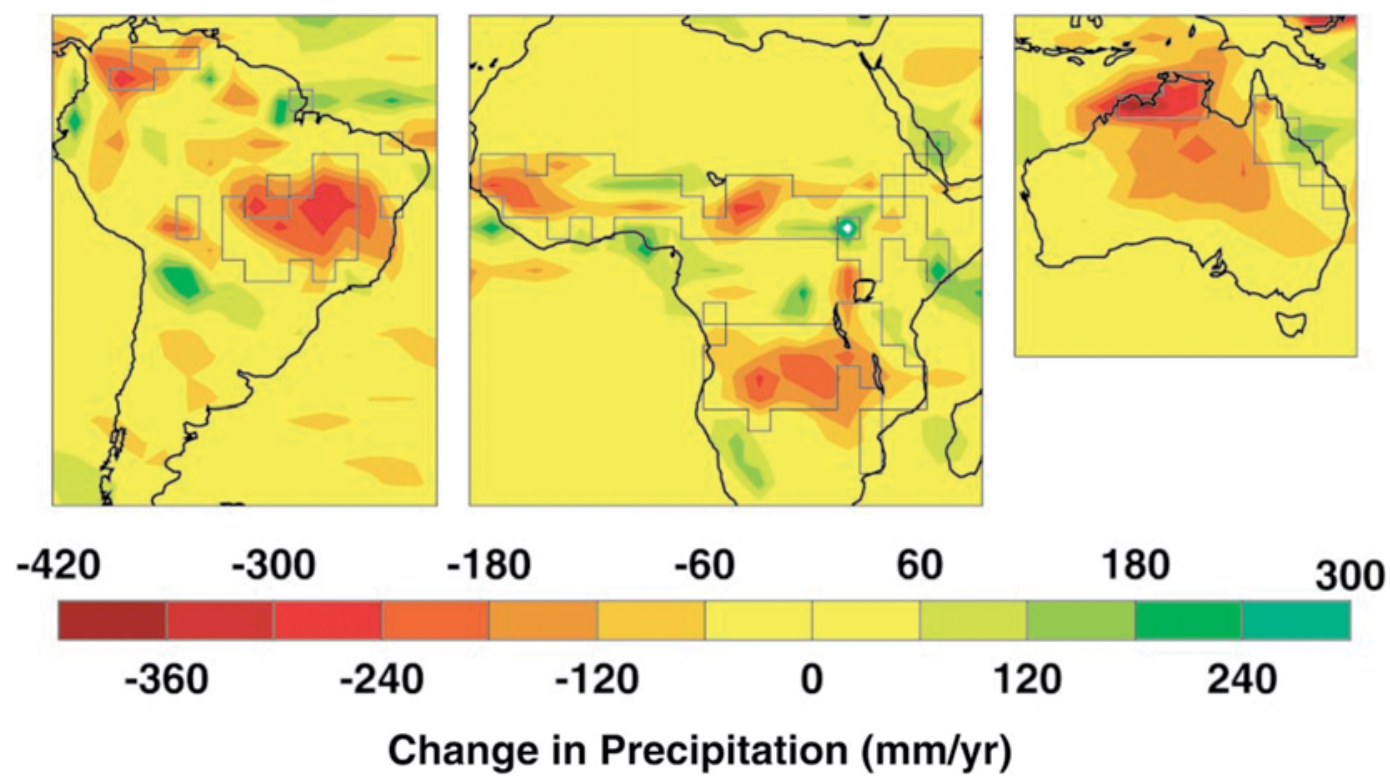

Figure 7 Change in the mean annual precipitation $(\mathrm{mm})$ resulting from conversion of tropical savanna to grassland (converted regions outlined in white). With the exception of savannas in northern Africa, all savanna regions exhibited a significant decrease in precipitation

Source: adapted from Hoffmann and Jackson (2000). 
the amount of rainfall. In addition to model sensitivities, differences between the results of Garrett (1982) and Clark and Arritt (1995) likely resulted from boundary-layer temperature and moisture profiles; the environment of the former study favoured convective development when surface temperatures increased whereas that of the latter study favoured convective development when surface moisture increased.

Taylor and Lebel (1998) investigated persistent convective-scale rainfall patterns using observational data (station spacing of $7.5-15 \mathrm{~km}$ ) from the HydrologicalAtmospheric Pilot Experiment in the Sahel (HAPEX-Sahel) in southwest Niger. They observed that during the wet months of July and August antecedent precipitation influenced rainfall patterns, particularly when intense, large-scale storms moved over strong gradients in surface evapotranspiration. When the time interval between events was one or two days, then surface evaporation rates from wet soil were relatively uniform and the rainfall pattern from a subsequent event was not strongly influenced by the preceding rainfall. When the time interval extended to three or four days, variability in root-level soil moisture caused vegetation to transpire in a pattern similar to the preceding rainfall event. This heterogeneity allowed rainfall patterns to persist from one event to another. In fact, when the gradient in deep soil moisture was strong, vegetation density could be influenced to provide an even stronger feedback and a more persistent condition that might continue for several weeks (Taylor et al., 1997). Secondary rainfall events that moved over a heterogeneous surface when heat flux gradients were weak (eg, windy or cloudy days) did not enhance the persistence of a previous rainfall pattern. Instead, the secondary rainfall homogenized the surface moisture.

Other studies suggest that the irrigation of crops in arid or semi-arid regions enhances local cloudiness and rainfall (Stidd, 1967; 1975; Joos, 1969; Changnon, 1973). In a study of the effect of irrigation on rainfall, Schickedanz (1976) observed statistically significant increases in warm-season rainfall over irrigated areas across the southern and central Great Plains. When irrigated years (1946-70) were compared with non-irrigated years (1931-45), rainfall over irrigated regions increased $14-26 \%$ in June, $57-91 \%$ in July, and $15-26 \%$ in August. The author hypothesized that the increased rainfall resulted from the presence of a relatively cool, moist dome over the irrigated regions.

Barnston and Schickedanz (1984) indicated that any enhancement to the low-level moisture field from irrigation required synopticscale uplift (eg, fronts, surface low-pressure systems) to increase cloud development and rainfall. Moore and Rojstaczer (2001) expanded upon the research of Barnston and Schickedanz (1984) and Schickedanz (1976) by examining precipitation patterns across the High Plains from 1957 to 1997. Three regions were examined: the Texas Panhandle (similar to the Schickedanz studies), eastern Colorado-western Kansas, and eastern Nebraska. In contrast to the previous studies, Moore and Rojstaczer (2001) did not find convincing evidence that irrigation induced increased rainfall within any of these regions. The authors hypothesized that climatological changes provided a greater influence on warm season rainfall than did regional irrigation; they believed that the Schickedanz results were affected by droughts during the 1930s.

Notaro et al. (2006) compared monthly precipitation data from the Climate Prediction Center Merged Analysis of Precipitation Dataset (Xie and Arkin, 1997) to monthly anomalies of fractional photosynthetically active radiation (FPAR) for 1982-2000. (FPAR is derived from satellite data (Myneni et al., 1997), linearly related to NDVI, and one measure of spatial and temporal changes in vegetation.) The authors documented that vegetation feedback on US annual precipitation was positive across the corn and soybean belt (Dakotas to Ohio) and negative across the winter wheat belt (southern plains). They attributed the differences in the results for these crops to both enhanced 
evapotranspiration from corn and soybeans (as compared to wheat) and irrigation of summer cropland. Seasonally, a positive feedback was observed for the south-central USA, including the winter wheat belt, during the winter and for the north-central USA, including the spring wheat belt, during the spring.

Using a single-column model that linked state-of-the-art soil, land, and cloud models, Sud et al. (2001) examined the influence of vegetation on rainfall in the US Southern Great Plains. They performed 600 simulations over four case-study days during June, July, and September using data from the Atmospheric Radiation Measurement Cloud and Radiation Testbed (ARM CART) site in the US Great Plains. The parameter space spanned six vegetation densities, five soil types, and four soil moisture profiles. Results showed a strong, positive feedback between evapotranspiration and precipitation for wet conditions and little or no feedback for drought conditions. Under wet conditions, increased vegetation led to the production of more rainfall; however, under dry conditions, the biosphere did little to relieve the drought. Trenberth and Guillemot (1996), in an analysis of the 1993 floods across the US Midwest, also documented that much of the precipitation during the summer floods appeared to result from local evapotranspiration, which produced a positive feedback. Zangvil et al. (2004), examining during seasons with highly disparate corn yields across the US Midwest, found that 16-19\% of local evapotransporation was recycled when daily, arealaveraged precipitation was greater than $8 \mathrm{~mm}$. For lesser amounts of daily precipitation, local moisture recycling ranged from 11 to $34 \%$ during May through August.

Dirmeyer (1994) documented results similar to those for the dry conditions in Sud et al. (2001). Using a general circulation model with a simplified version of the Simple Biosphere (SiB) Model (Sellers et al., 1986; Xue et al., 1991), year-long simulations were conducted to determine if changes in grassland that occur during a drought (eg, dormancy) could feedback on the drought itself. Three cases were compared to a control case and were initialized with the following springtime conditions: (1) low initial soil moisture (2) dormant vegetation settings, and (3) both minimal soil moisture and dormant vegetation (Figure 8). The former two simulations produced moderate drought during part or all of the summer season. The latter case resulted in a severe and extended drought, marked by changes in most variables that were greater than the sum of those for the former two cases. Of interest, although dormant vegetation might have intensified the meteorological drought, it served to protect the soil from being increasingly depleted of moisture.

Taylor et al. (2002) examined differences in wet-season rainfall across the Sahel resulting from vegetation changes documented between 1961 and 1996 and those projected from 1961 to 2015 . The authors used a general circulation model (Hadley Centre Unified Model from the UK Met Office; Pope et al., 2000) and estimated land use and their associated vegetative characteristics (eg, albedo, roughness length) to study rainfall amounts during July, August, and September. Results indicated that reductions in wet-season rainfall of 4.6\% (1961-96) and $8.7 \%$ (1961-2015) were associated with the simulated deforestation and agricultural expansion. The decrease in vegetation delayed the onset of the wet season in July rather than consistently reducing the amount of rainfall throughout the wet season.

\section{Impact on differential heating}

Several observational studies indicated that near-surface air temperatures were lower over irrigated regions when compared to bare soil areas exposed to similar conditions. Reported temperature gradients include $1-2^{\circ} \mathrm{C}$ across $8 \mathrm{~km}$ (De Vries and Birch, 1961), 1.5 ${ }^{\circ} \mathrm{C}$ across $17 \mathrm{~km}$ (Davenport and Hudson, 1967), and $3.1^{\circ} \mathrm{C}$ across about $10 \mathrm{~km}$ (Burman et al., 1975). Over irrigated cotton, Voronstov (1963) observed a significant cold pool that extended $\sim 400 \mathrm{~m}$ above ground, with the horizontal temperature gradient weakening around 700 m. Dzerdzeevskii (1963) measured a 


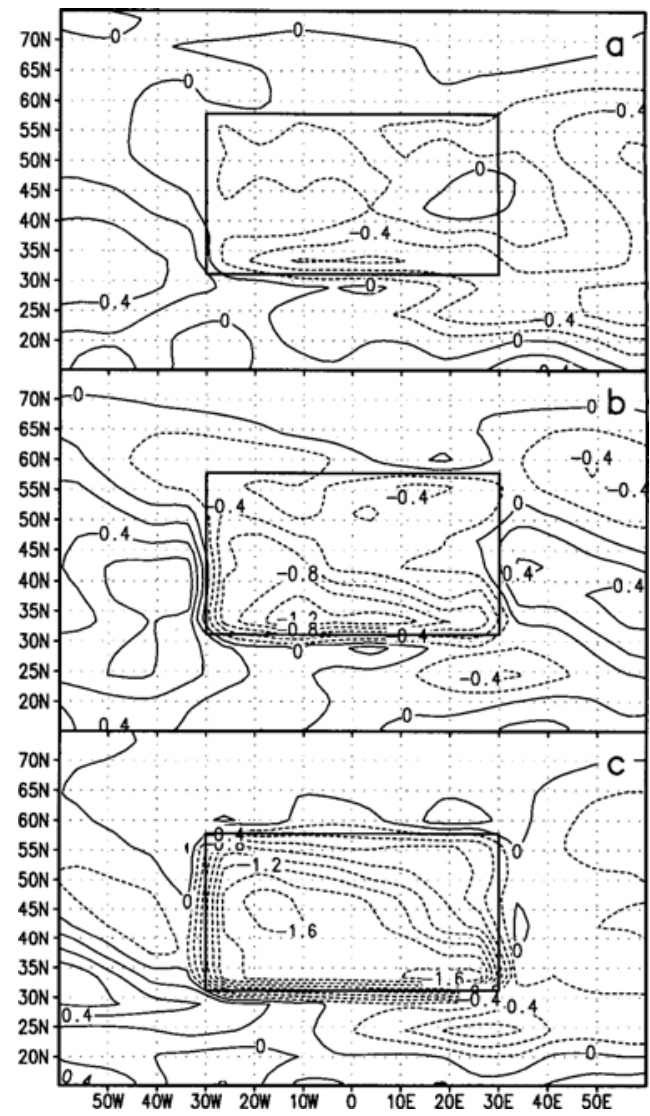

Figure 8 Seasonal mean anomalies in evapotranspiration rate $\left(\mathrm{mm} \mathrm{d}^{-1}\right)$ for simulations representing (a) dormant vegetation (b) low initial soil moisture, and (c) both minimal soil moisture and dormant vegetation. Contour interval is $0.2 \mathrm{~mm} \mathrm{~d}^{-1}$, and the solid box in the centre denotes the location of an idealized continent where the soil moisture and vegetation parameters were altered from those of the control case. Results indicate that drought severity increases when low soil moisture is combined with dormant vegetation Source: Dirmeyer (1994); courtesy of the American Meteorological Society.

similar cold pool above irrigated areas compared to nearby steppe. Observations detected that the cold pool extended to about $1 \mathrm{~km}$ when the surface was dry and to about $600 \mathrm{~m}$ during saturated conditions.

McPherson et al. (2004) found that as vegetation grew across the wheat belt maximum daily temperatures were lower than those measured over adjacent regions of dormant grasslands (Table 1). Using Oklahoma Mesonet data (McPherson et al., 2007) from 1994 through 2001, the lower temperatures over the wheat belt were shown to be statistically significant at the $95 \%$ confidence level for November (cooler by $0.54^{\circ} \mathrm{C}$, on average), December $\left(0.47^{\circ} \mathrm{C}\right)$, January $\left(0.56^{\circ} \mathrm{C}\right)$, February $\left(0.51^{\circ} \mathrm{C}\right)$, and April $\left(0.45^{\circ} \mathrm{C}\right)$. After the wheat was harvested, maximum daily temperature data revealed a statistically significant warm anomaly across the wheat belt as

Table 1 Mean values of maximum daily temperature (TMAX; ${ }^{\circ} \mathrm{C}$ ) for November through August using Oklahoma Mesonet data from 1994-2001. From west to east, the regions were labelled 'West', 'Wheat', and 'East' and represented Oklahoma's northwestern grasslands, northern winter wheat belt, and eastern mixture of grasslands and hardwood forest, respectively. Bold values are anomalous monthly means, defined for this study as a monthly mean for 'Wheat' that did not have a numerical value between the monthly mean values for 'West' and 'East'. (Adapted from McPherson et al., 2004; courtesy of the American Meteorological Society)

TMAX

\begin{tabular}{lrrr}
\hline & West & Wheat & East \\
\hline November & 15.88 & $\mathbf{1 5 . 3 3}$ & 15.86 \\
December & 9.44 & $\mathbf{9 . 0 6}$ & 9.61 \\
January & 8.81 & $\mathbf{8 . 0 3}$ & 8.37 \\
February & 12.69 & $\mathbf{1 2 . 3 5}$ & 13.03 \\
March & 15.33 & $\mathbf{1 5 . 0 2}$ & 15.66 \\
April & 21.23 & $\mathbf{2 0 . 9 2}$ & 21.51 \\
May & 26.76 & 26.69 & 26.12 \\
June & 31.31 & $\mathbf{3 1 . 6 5}$ & 30.05 \\
July & 35.05 & $\mathbf{3 5 . 3 6}$ & 33.54 \\
August & 34.52 & $\mathbf{3 4 . 8 3}$ & 33.97 \\
\hline
\end{tabular}


compared to adjacent grasslands during June (warmer by $0.97^{\circ} \mathrm{C}$, on average), July $\left(1.07^{\circ} \mathrm{C}\right)$, and August $\left(0.59^{\circ} \mathrm{C}\right)$. Using Oklahoma Mesonet data from 1994 to 2002, Haugland and Crawford (2005) also noted a monthly averaged temperature gradient across the wheat belt. Mid-afternoon potential temperatures averaged $0.9^{\circ} \mathrm{C}$ lower in March and $0.4^{\circ} \mathrm{C}$ higher during the summer over the wheat belt as compared to adjacent grasslands.

Segal et al. (1989) used satellite imagery, surface observations, and aircraft measurements of the PBL over northeast Colorado during CINDE (Convective Initiation and Downburst Experiment) in 1987 to examine differential heating between irrigated crops and dry, sparsely vegetated land. Satellite infrared temperatures of surface conditions indicated that a pool of air over irrigated regions was $\sim 10^{\circ} \mathrm{C}$ cooler than that across the nearby dry land. Surface and aircraft measurements verified the existence of the cold pool, though its gradient was less than that measured by satellite. The cold pool was determined to extend at least $445 \mathrm{~m}$ above ground (the highest aircraft measurement). Radiosonde measurements on 28 July 1987 around 1315 LDT indicated that the shallowest PBL existed over the irrigated land, the highest potential temperature within the PBL was over the dry land, and the highest mixing ratio overlaid the irrigated land. All aircraft flights observed notably higher equivalent potential temperatures over the irrigated plots.

The spatial variation of vegetation and the associated gradients created in sensible heat flux can change the evolution of surface baroclinic zones, especially when a variation of vegetation density or type is accompanied by substantial soil moisture in the root zone. Even though surface evaporation over bare, moist soil can be substantial, latent heat fluxes are enhanced over a longer period of time when moist soil underlies vegetation, allowing roots to access moisture through an extended soil depth (Wetzel and Woodward, 1987; Rabin et al., 1990; Chang and Wetzel, 1991). Focusing on the development of severe storms, Chang and Wetzel (1991) modelled the impact of spatial variations of soil moisture and vegetation on boundary layer evolution. They determined that vegetation discontinuities on the meso- $\alpha$ scale either created new or enhanced existing surface gradients both by compacting the spatial rate of temperature change into mesoscale regions and by accumulating moisture within a shallower boundary layer. The differential heating intensified the surface pressure gradient, which, in turn, enhanced both warm advection and convergence across the weak surface boundary. By destabilizing the local environment, these foliage gradients became preferred regions for convective initiation in conditionally unstable environments. Without vegetation, surface evaporation alone was insufficient to establish strong thermal gradients at the surface.

\section{Impact on mesoscale circulations}

On the mesoscale, variations in soil moisture or soil texture have been shown to significantly influence PBL characteristics and mesoscale circulations (Zhang and Anthes, 1982; Ookouchi et al., 1984; Mahfouf et al., 1987; Yan and Anthes, 1988; Schadler, 1990; Lynn et al., 1998). These mesoscale circulations can produce mesoscale fluxes greater than their associated turbulent fluxes, and they do so predominantly in narrow zones a few hundred metres wide (Mahrt et al., 1994; Lynn et al., 1995). As a result, well-defined mesoscale circulations aid the transport of heat and moisture throughout the PBL and advance the potential erosion of any capping inversion. Sea-breeze-like fronts moving from opposing wet patches toward the centre of a dry patch may collide and enhance the solenoidal circulation, particularly if the dry patch is wide enough for the collision to occur shortly after moist convection initiates (Lynn et al., 1998).

Differential heating caused by sensible heat gradients across adjacent regions of active vegetation and dry, bare soil also can generate a sea breeze-like circulation, called a 'vegetation breeze' (Purdom and Gurka, 1974; Mahfouf et al., 1987; Segal et al., 1988; Mahrt et al., 1994; Hong et al., 1995; Lee and 
Kimura, 2001). Similar circulations have been modelled across boundaries of distinct vegetation types (Pinty et al., 1989; Pielke et al., 1991). Observations indicate that vegetation breezes have an appreciable effect on the formation of shallow cumulus clouds (Garrett, 1982; Rabin et al., 1990). Numerical simulations demonstrate that these circulations can provide preferred regions to focus atmospheric instabilities and to initiate convective development (Sun and Ogura, 1979; Garrett, 1982; Mahfouf et al., 1987; Chang and Wetzel, 1991; Chen and Avissar, 1994).

Anthes (1984) authored the landmark study on mesoscale circulations that result from alternating bands of dense vegetation and bare soil. Given marginally unstable atmospheric conditions and the differential heating generated by these bands, mesoscale circulations of similar intensity to sea-breeze circulations were hypothesized to be generated in a semiarid region. Anthes (1984) applied linear theory to demonstrate analytically that, as a result of these circulations, convective rainfall would be significantly greater when generated by vegetation/bare land contrasts than by either uniformly vegetated or uniformly bare surfaces.
In addition, a length scale between 50 and $100 \mathrm{~km}$ was deemed to be the most effective to generate circulations deep enough to initiate moist convection. Similarly, Chen and Avissar (1994) and Lynn et al. (1995) noted that heterogeneities must be at least $10 \mathrm{~km}$ wide to establish mesoscale fluxes. At scales smaller than $10 \mathrm{~km}$, turbulent mixing overpowered horizontal pressure gradient forces.

Using two-dimensional mesoscale simulations (Pielke, 1984) under clear sky conditions and weak synoptic flow, Segal et al. (1988) demonstrated that only weak circulations developed when bare, wet soil was adjacent to non-stressed vegetation or when non-stressed vegetation was adjacent to water. Weak circulations resulted because the amount of evaporation from bare, wet soil or water was similar to that from non-stressed vegetation. Thermal circulations comparable in intensity to a sea breeze, however, were generated by covering half of the mesoscale domain with dense, unstressed vegetation and the other half of the domain with dry, bare soil (Figure 9). In particular, a strong vegetation breeze was established when simulating an event whereby a heavy uniform rainfall was followed by several
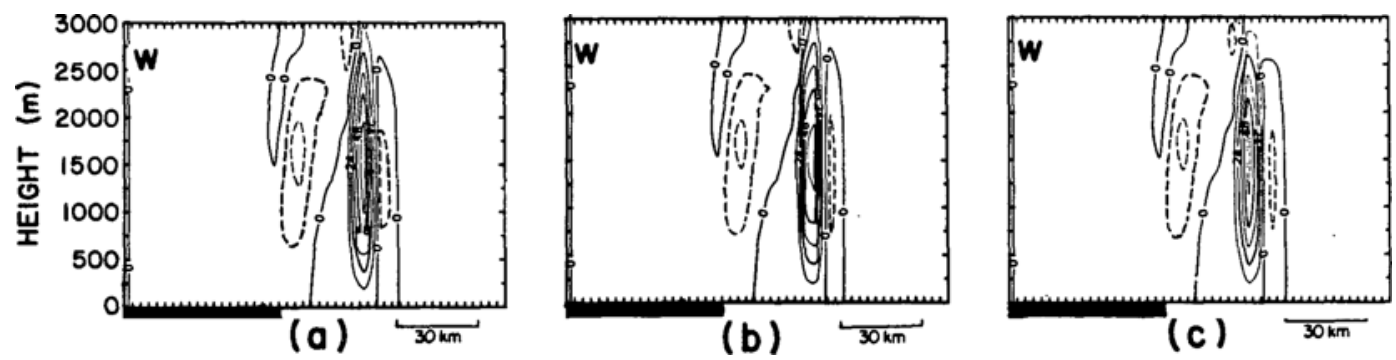

Figure 9 Vertical cross-sections of the vertical wind $\left(w ; \mathrm{cm} \mathrm{s}^{-1}\right)$ for three simulations: (a) 25\% volumetric soil wetness under vegetation and $5 \%$ wetness under bare soil; (b) same as (a) except using a different soil-plant module; and (c) 5\% soil moisture in the upper $5 \mathrm{~cm}$ and $25 \%$ below across both vegetation and bare soil. The thick, dark segment denotes the horizontal extent of the vegetation. Values are shown for 1400 local standard time. All three cases demonstrate a vertical circulation of similar magnitude to a sea breeze (not shown) Source: adapted from Segal et al. (1988); courtesy of the American Meteorological Society. 
dry days. In this case, the surface of the bare soil became dry whereas the vegetation accessed its substantial supply of root-level moisture for evapotranspiration.

Four additional experiments by Segal et al. (1988) are salient. First, as foliage density decreased, circulation intensity reduced. Second, when simulated environmental stresses were imposed, latent heat flux over the vegetation reduced and the vegetation breeze decreased. Third, when swaths of dry, bare soil flanked a swath of non-stressed vegetation, two circulation cells were established, with upward vertical velocities evident over both bare soil patches. Fourth, when a weak easterly crosswind $\left(3 \mathrm{~m} \mathrm{~s}^{-1}\right)$ was imposed on this last simulation, a distortion of the two-cell circulation occurred. In particular, significant vertical motion was noted only over the eastern swath of bare soil, and convergence at the windward edge of the vegetation belt was enhanced.

Segal and Arritt (1992) noted that regions where vegetation breezes might be observed in nature typically were smaller in areal extent than were their numerically simulated counterparts (because of the idealized nature of the simulations). In particular, past observational studies were characterized by non-uniform regions (eg, in size, soil moisture, vegetation density), small zones where the sensible heat flux was suppressed, and periods when moderate synoptic or mesoscale flows obscured the land-atmosphere interactions. Evaluating several real-world studies of possible vegetation breezes, Segal and Arritt (1992) documented that vegetated areas used in these studies typically were $10-100 \mathrm{~km}$ wide, with a band of decreasing foliage that extended $1-10 \mathrm{~km}$ beyond the area's defined boundary. In addition, these vegetated regions had foliage that averaged $50 \%$ to $90 \%$ coverage and sensible heat fluxes measured to be $20 \%$ to $50 \%$ of those over the surrounding area.

Souza et al. (2000) did measure a vegetation-induced circulation across sloping terrain in the state of Rondônia, Brazil $\left(10^{\circ} \mathrm{S}\right.$, $\left.62^{\circ} \mathrm{W}\right)$. Using near-surface and upper-air data for a 10-day period during mid-August 1994, the authors documented a perturbation wind (observed, ensemble-averaged wind minus mean synoptic, ensemble-averaged wind) within the lowest $3 \mathrm{~km}$ of the atmosphere that was directed from the forest toward the deforested pasture. A perturbation wind in the opposite direction was measured between 3 and $5 \mathrm{~km}$ above ground. The measured circulation was strongest between 1100 and 1400 local time, when maximum surface heating occurred.

Doran et al. (1995) documented a possible 'farm breeze' circulation across a boundary between steppe and irrigated cropland near Boardman, WA on 11 June 1992 (Figure 10). Throughout that day, winds over the steppe were from the southwest or west, perpendicular to the steppe-cropland boundary and blowing from steppe to farmland. Over the farm, however, southwest or west winds during the morning veered to the north and northeast during the early afternoon. The wind shift over the farm was measured both by surface stations and by three sodars that measured winds at $60 \mathrm{~m}$ above ground. With no change in the large-scale wind pattern nor a terrain-related change in the wind field, the authors attributed this wind shift to a farm breeze circulation. Sensible heat fluxes between 1000 and 1530 PDT averaged about $300 \mathrm{~W} \mathrm{~m}^{-2}$ over the steppe yet only $60 \mathrm{~W}$ $\mathrm{m}^{-2}$ over the farm.

Inspecting 21-day ensemble-averages of the perturbation wind field (observed surface wind minus daily mean surface wind), Smith et al. (1994) discovered perturbation winds blowing across a vegetation gradient at 1515 LDT during the fifth FIFE intensive field campaign. The perturbation winds were directed from an area of dense, green vegetation (and low sensible heat fluxes) toward an area of sparser, drier vegetation (and high sensible heat fluxes). A three-day ensemble average depicted even more intense perturbation winds. The authors attributed these winds to a local, direct circulation that was established by the sensible heat gradient 

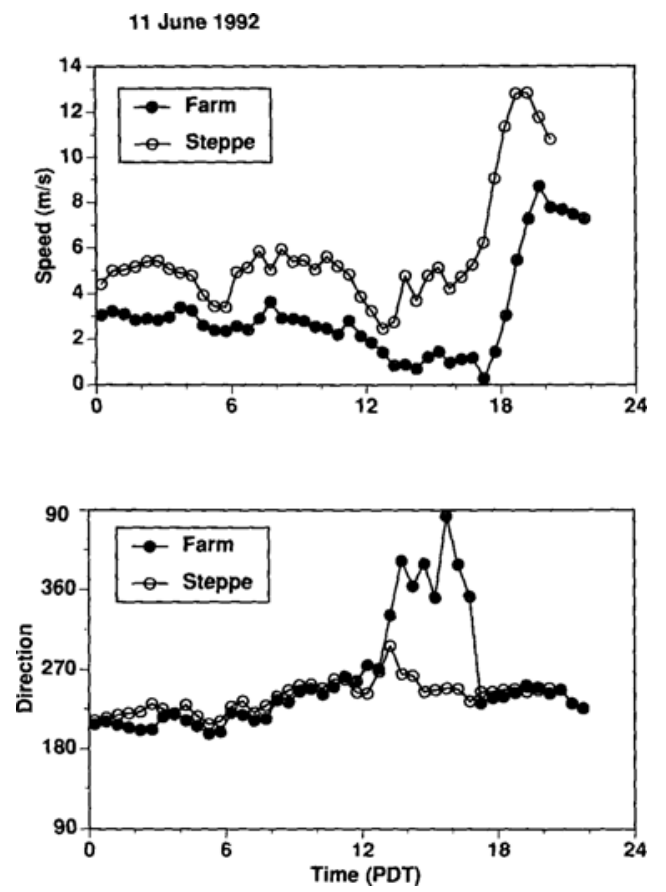

Figure 10 Wind speed $\left(\mathrm{m} \mathrm{s}^{-1}\right)$ and direction (deg) on 11 June 1992 over steppe (open circles) and farmland (filled circles) at heights of 9 and $4 \mathrm{~m}$, respectively. The shift in wind direction between 1200 and 1800 Pacific Daylight Time (PDT) at the farm site indicates a possible vegetation breeze generated by the gradient in vegetation from farm to steppe Source: Doran et al. (1995); courtesy of the American Meteorological Society.

between the dense and sparse vegetation areas. Wai and Smith (1998) studied upperair observations for this same experiment and found that the secondary circulation had a vertical extent of at least $500 \mathrm{~m}$. In addition, the circulation was not weakened substantially by convective clouds, provided that the horizontal temperature gradient at the surface was maintained. Substantial rainfall and cold-air advection, however, did disrupt the direct circulation.

\section{Discussion}

The atmospheric sciences community has come to a better understanding of how vegetation affects local and regional weather and climate. These scientists long have appreciated the importance of global atmospheric patterns to the growth and distribution of natural vegetation, cropland, and rangeland. Until recently, however, surface observing networks and numerical models were not developed sufficiently to document and examine the importance of vegetation feedbacks on the atmosphere. Fortunately, many surface observation stations now include measurements of soil temperature, soil moisture, $\mathrm{CO}_{2}$, evapotranspiration, latent and sensible heat fluxes, and related variables and processes. In addition, mesoscale models have begun to incorporate land-surface modules that simulate vegetative coverage. Although these measurements are not ubiquitous and the computational modules typically are not sophisticated, the increased attention to vegetation-atmosphere interactions will aid weather forecasting (eg, high temperature forecasts) as well as long-term climate predictions.

The transformation of regional vegetation coverage to different land uses, especially the substitution of native forest with cropland, can result in local or regional climate changes as significant as those ascribed to the enhancement of atmospheric greenhouse gases by humans. Hence, it is important that scientists help policymakers put into perspective the consequences of various sources of weather modification.

\section{Acknowledgements}

I appreciate the helpful comments and encouragement provided by Kenneth Crawford, David Stensrud, and Peter Lamb. Thanks to Ryan Davis for drawing the schematic diagrams. This manuscript is based upon work supported by the National Science Foundation under NSF-0074852. 


\section{References}

Aase, J.K. and Siddoway, F.H. 1982: Evaporative flux from wheat and fallow in semiarid climate. Soil Science Society of America Journal 46, 619-26.

Adegoke, J.O., Pielke, R.A. Sr, Eastman, J., Mahmood, R. and Hubbard, K.G. 2003: Impact of irrigation on midsummer surface fluxes and temperature under dry synoptic conditions: a regional atmospheric model study of the USA High Plains. Monthly Weather Review 131, 556-64.

Anthes, R.A. 1984: Enhancement of convective precipitation by mesoscale variations in vegetative covering in semiarid regions. Journal of Climate and Applied Meteorology 23, 541-54.

Anthes, R.A. and Warner, T.T. 1978: Development of hydrodynamic models suitable for air pollution and other mesometeorological studies. Monthly Weather Review 106, 1045-78.

Avissar, R. and Pielke, R.A. 1989: A parameterization of heterogeneous land surfaces for atmospheric numerical models and its impact on regional meteorology. Monthly Weather Review 117, 2113-36.

Ba, M.B., Nicholson, S.E. and Frouin, R. 2001: Satellite-derived surface radiation budget over the African continent. Part II: climatologies of the various components. Journal of Climate 14, 60-76.

Barnston, S.G. and Schickedanz, P.T. 1984: The effect of irrigation on warm season precipitation in the southern Great Plains. Journal of Climate and Applied Meteorology 23, 865-88.

Bechtold, P., Pinty, J.-P. and Mascart, F. 1991: A numerical investigation of the influence of large-scale winds on sea-breeze- and inland-breeze-type circulations. Journal of Applied Meteorology 9, 1268-79.

Betts, A.K. and Ball, J.H. 1997: Albedo over the boreal forest. Journal of Geophysical Research 102(D24), 28,901-909.

Blyth, E.M., Dolman, A.J. and Noilhan, J. 1994: The effect of forest on mesoscale rainfall: an example from HAPEX-MOBILHY. Journal of Applied Meteorology 33, 445-54.

Bonan, G.B. 2001: Observational evidence for reduction of daily maximum temperatures by croplands in the Midwest United States. Journal of Climate, 14, 2430-42.

Burman, R.D., Wright, J.L. and Jensen, M.E. 1975: Changes in climate and estimated evaporation across a large irrigated area in Idaho. Transactions of the ASAE 18, 1089-93.

Carleton, A., Travis, D., Arnold, D., Brinegar, R., Jelinski, D.E. and Easterling, D.R. 1994: Climaticscale vegetation-cloud interactions during drought using satellite data. International Journal of Climatology $14,593-623$

Chang, J.T. and Wetzel, P.J. 1991: Effects of spatial variations of soil moisture and vegetation on the evolution of a prestorm environment: a numerical case study. Monthly Weather Review 119, 1368-90.
Changnon, S.A. 1973: Weather modification in 1972: up or down? Bulletin of the American Meteorological Society 54, 642-46.

Chen, F. and Avissar, R. 1994: Impact of land-surface moisture variability on local shallow convective cumulus and precipitation in large-scale models. Journal of Applied Meteorology 33, 1382-401.

Clark, C.A. and Arritt, R.W. 1995: Numerical simulations of the effect of soil moisture and vegetation cover on the development of deep convection. Journal of Applied Meteorology 34, 2029-45.

Cutrim, E., Martin, D.W. and Rabin, R. 1995: Enhancement of cumulus clouds over deforested lands in Amazonia. Bulletin of the American Meteorological Society 76, 1801-805.

Dai, A., Del Genio, A.D. and Fung, I.Y. 1997: Clouds, precipitation, and temperature range. Nature 386, 665-66.

Davenport, D.C. and Hudson, J.P. 1967: Meteorological observations and Penman estimates along a $17 \mathrm{~km}$ transect in the Sudan Gezira. Agricultural Meteorology 4, 405-14.

De Vries, D.A. and Birch, J.W. 1961: The modification of climate near the ground by irrigation for pastures on the Riverine Plain. Australian Journal of Agricultural Research 12, 260-72.

Dirmeyer, P.A. 1994: Vegetation stress as a feedback mechanism in midlatitude drought. Journal of Climate, 7, 1463-83.

Doran, J.C., Hubbe, J.M., Kirkham, R.R., Shaw, W.J., Whiteman, C.D., Barnes, F.J., Cooper, D., Porch, W., Coutler, R.L., Cook, D.R., Hart, R.L., Gao, W., Martin, T.J., Shannon, J.D., Crawford, T.L., Baldocchi, D.D., Dobosy, R.J., Meyers, T.P., Balick, L., Dugas, W.A., Hicks, R., Fritschen, L., Hipps, L., Swiatek, E. and Kunkel, K.E. 1992: The Boardman Regional Flux Experiment. Bulletin of the American Meteorological Society 73, 1785-96.

Doran, J.C., Shaw, W.J. and Hubbe, J.M. 1995: Boundary layer characteristics over areas of inhomogeneous surface fluxes. Journal of Applied Meteorology 34, 559-71

Durre, I. and Wallace, J.M. 2001: The warm season dip in diurnal temperature range over the eastern United States. Journal of Climate 14, 354-60.

Dzerdzeevskii, B.L. 1963: Meteorological parameters of the surface air layer over humid and dry sectors of the Trans-Volga Steppe. In Dzerdzeevskii, B.L., editor, Sukhoveis and drought control, Jerusalem: Israel Program for Scientific Translations, 162-80.

Easterling, D.R., Karl, T.R., Mason, E.H., Hughes, P.Y. and Bowman, D.P. 1996: United States Historical Climatology Network (US HCN) monthly temperature and precipitation data. Oak Ridge National Laboratory ORNL/CDIAC-87, NDP019/R3, Carbon Dioxide Information Analysis Center, 280 pp. 
Fitzjarrald, D.R., Acevedo, O.C. and Moore, K.E. 2001: Climatic consequences of leaf presence in the eastern United States. Journal of Climate, 14, 598-614.

Freedman, J.M., Fitzjarrald, D.R., Moore, K.E. and Sakai, R.K. 2001: Boundary layer clouds and vegetation-atmosphere feedbacks. Journal of Climate 14, 180-97.

Garrett, A.J. 1982: A parameter study of interactions between convective clouds, the convective boundary layer, and forested surface. Monthly Weather Review 110, 1041-59.

Grell, G.A., Dudhia, J. and Stauffer, D.R. 1994: A description of the fifth-generation Penn State/ NCAR mesoscale model (MM5). NCAR Technical Note, NCAR/TN-398+STR, 117 pp.

Haugland, M.J. and Crawford, K.C. 2005: The diurnal cycle of land-atmosphere interactions across Oklahoma's winter wheat belt. Monthly Weather Review 133, 120-30.

Heim, J.E. 1993: Surface properties and their effect on deep cumulus convection over uniform terrain. MS thesis, Department of Physics and Astronomy, University of Kansas, $95 \mathrm{pp}$.

Hoffmann, W.A. and Jackson, R.B. 2000: Vegetation-climate feedbacks in the conversion of tropical savanna to grassland. Journal of Climate 13, 1593-1602.

Hong, X., Leach, M.J. and Raman, S. 1995: A sensitivity study of convective cloud formation by vegetation forcing with different atmospheric conditions. Journal of Applied Meteorology 34, 2008-28.

Huang, C.Y. 1990: A mesoscale planetary boundary layer model for simulations of topographically induced circulations. PhD dissertation, North Carolina State University, $253 \mathrm{pp}$.

Huang, C.Y. and Raman, S. 1991a: Numerical simulation of January 28 cold air outbreak during GALE. Part I: the model and sensitivity tests of turbulence closures. Boundary-Layer Meteorology 55, 381-407.

- 1991b: Numerical simulation of January 28 cold air outbreak during GALE. Part II: the mesoscale circulation and marine boundary layer. Boundary-Layer Meteorology 56, 51-81.

Jarvis, P.G., Miranda, R.S. and Meutzelfeldt, R.I. 1985: Modeling canopy exchanges of water vapour and carbon dioxide in coniferous forest plantations. In Hutchison, B.A. and Hicks, B.B., editors, The forest-atmosphere interaction, Reidel, 521-42.

Joos, A. 1969: Recent rainfall patterns in the Great Plains. Informal publication at AMS Symposium, Madison, WI, 21 October.

Lakhtakia, M.N. and Warner, T.T. 1994: A comparison of simple and complex treatments of surface hydrology and thermodynamics suitable for mesoscale atmospheric models. Monthly Weather Review 122, 880-96.
Lanicci, J.M., Carlson, T.N. and Warner, T. T. 1987 : Sensitivity of the Great Plains severe-storm environment to soil-moisture distribution. Monthly Weather Review 115, 2660-73.

Lee, S. T. and Kimura, F. 2001: Comparative studies in the local circulations induced by land-use and by topography. Boundary-Layer Meteorology 101, 157-82.

Lee, T.J. 1992: The impact of vegetation on the atmospheric boundary layer and convective storms. $\mathrm{PhD}$ dissertation, Colorado State University, 137 pp.

LeMone, M.A., Grossman, R.L., Coulter, R.L., Wesley, M.L., Klazura, G.E., Poulos, G.S., Blumen, W., Lundquist, J.K., Cuenca, R.H., Kelly, S.F., Brandes, E.A., Oncley, S.P., McMillen, R.T. and Hicks, B.B. 2000: Land-atmosphere interaction research, early results, and opportunities in the Walnut River Watershed in Southeast Kansas: CASES and ABLE. Bulletin of the American Meteorological Society 81, 757-80.

Lynn, B.H., Rind, D. and Avissar, R. 1995: The importance of mesoscale circulations generated by subgrid-scale landscape-heterogeneities in general circulation models. Journal of Climate 8, 191-205.

Lynn, B.H., Tao, W.-K. and Wetzel, P.J. 1998: A study of landscape-generated deep moist convection. Monthly Weather Review 126, 928-42.

Mahfouf, J.-F., Richard, E. and Mascart, P. 1987: The influence of soil and vegetation on the development of mesoscale circulations. Journal of Climate and Applied Meteorology 26, 1483-95.

Mahrt, L., Sun, J. S., Vickers, D., MacPherson, J.I., Pederson, J.R. and Desjardins, R.L. 1994: Observations of fluxes and inland breezes over a heterogeneous surface. Journal of the Atmospheric Sciences 51, 2484-99.

Matthews, E. and Rossow, W.B. 1987: Regional and seasonal variations of surface reflectance from satellite observations at $0.6 \mathrm{~mm}$. Journal of Climate and Applied Meteorology 26, 170-202.

McPherson, R.A. and Stensrud, D.J. 2005: Influences of a winter wheat belt on the evolution of the boundary layer. Monthly Weather Review 133, 2178-99.

McPherson, R.A., Fiebrich, C., Crawford, K.C., Elliott, R.L., Kilby, J.R., Grimsley, D.L., Martinez, J.E., Basara, J.B., Illston, B.G., Morris, D.A., Kloesel, K.A., Stadler, S.J., Melvin, A.D., Sutherland, A.J., Shrivastava, H., Carlson, J.D., Wolfinbarger, J.M., Bostic, J.P. and Demko, D.B. 2007: Statewide monitoring of the mesoscale environment: A technical update on the Oklahoma Mesonet. Journal of Atmospheric and Oceanic Technology, 24, 301-21.

McPherson, R.A., Stensrud, D.J. and Crawford, K.C. 2004: The impact of Oklahoma's winter wheat belt on the mesoscale environment. Monthly Weather Review 132, 405-21. 
Mintz, Y. 1984: The sensitivity of numerically simulated climates to land-surface boundary conditions. In Houghton, J.T., editor, The global climate, Cambridge: Cambridge University Press, 79-105.

Moore, K.E., Fitzjarrald, D.R., Sakai, R.K., Goulden, M.L., Munger, J.W. and Wofsy, S.C. 1996: Seasonal variation in radiative and turbulent exchange at a deciduous forest in Central Massachusetts. Journal of Applied Meteorology 35, 122-34.

Moore, N. and Rojstaczer, S. 2001: Irrigation-induced rainfall and the Great Plains. Journal of Applied Meteorology 40, 1297-309.

Myneni, R.B., Nemani, R.R. and Running, S.W. 1997 : Estimation of global leave area index and absorbed PAR using radiative transfer models. IEEE Transactions on Geoscience and Remote Sensing 35, 1380-93.

Nair, U.S., Lawton, R.O., Welch, R.M. and Pielke, R.A. Sr 2003: Impact of land use on Costa Rican tropical montane cloud forests: sensitivity of cumulus cloud characteristics to lowland deforestation. Journal of Geophysical Research 108(D7), 4206, DOI: 10.1029/2001JD001135.

Nickerson, E.C., Richard, E., Rosset, R. and Smith, D.R. 1986: The numerical simulation of clouds, rain, and airflow over the Vosges and Black Forest mountains: a meso-b model with parameterised microphysics. Monthly Weather Review 114, 398-414.

Notaro, M., Liu, Z. and Williams, J.W. 2006: Observed vegetation-climate feedbacks in the United States. Journal of Climate 19, 763-86.

Ookouchi, Y., Segal, M., Kessler, R.C. and Pielke, R.A. 1984: Evaluation of soil moisture effects on generation and modification of mesoscale circulations. Monthly Weather Review 11, 2281-92.

Otterman, J. 1976: Reply. Science 194, 748-49.

- 1981: Satellite and field studies of man's impact on the surface in arid regions. Tellus 33, 68-77.

Pielke, R.A. 1984: Mesoscale meteorological modeling. Academic Press, 612 pp.

Pielke, R.A., Dalu, G.A., Snook, J.S., Lee, T.J. and Kittel, T.G.F. 1991: Nonlinear influence of mesoscale land use on weather and climate. Journal of Climate 4, 1053-69.

Pinty, J.-P., Mascart, P., Richard, E. and Rosset, R. 1989: An investigation of mesoscale flows induced by vegetation inhomogeneities using an evapotranspiration model calibrated against HAPEXMOBILHY data. Journal of Applied Meteorology 28, 976-92.

Pope, V.D., Gallani, M.L., Rowntree, P.R. and Stratton, R.A. 2000: The impact of new physical parametrizations in the Hadley Centre climate model HadAM3. Climate Dynamics 16, 123-46.

Purdom, J.F.W. and Gurka, J.J. 1974: The effect of early morning cloud on afternoon thunderstorm development. Preprints, 5th Conference on Weather Analysis and Forecasting, St Louis, American Meteorogical Society, 58-60.
Rabin, R.M. 1977: The surface energy budget of a summer convective period. MS thesis, McGill University, Montreal, 125 pp.

Rabin, R.M., Stadler, S., Wetzel, P.J., Stensrud, D.J. and Gregory, M. 1990: Observed effects of landscape variability on convective clouds. Bulletin of the American Meteorological Society 71, 272-80.

Reddy, S.J. 1983: A simple method of estimating the soil water balance. Agricultural Meteorology 28, 1-17.

Rogerson, T.L. 1976: Soil water deficits under forested and cleared areas in northern Arkansas. Soil Science Society of America Journal 40, 802-805.

Rosenan, N. 1963: Changes of climate. Proceedings Rome Symposium, UNESCO, WMO, 67-73.

Schadler, G. 1990: Triggering of atmospheric circulations by moisture inhomogeneities of the earth's surface. Boundary-Layer Meteorology 51, 1-30.

Schickedanz, P.T. 1976: The effect of irrigation on precipitation in the Great Plains. NSF-RANN, Grant Gl-43871, Final Report, Atmospheric Sciences Section, Illinois State Water Survey, Urbana, $105 \mathrm{pp}$.

Schwartz, M.D. 1992: Phenology and springtime surface-layer change. Monthly Weather Review 120, 2570-78.

Segal, M. and Arritt, R.W. 1992: Nonclassical mesoscale circulations caused by surface sensible heat-flux gradients. Bulletin of the American Meteorological Society 73, 1593-604.

Segal, M., Arritt, R.W. and Clark, C. 1995: Scaling evaluation of the effect of surface characteristics on potential for deep convection over uniform terrain. Monthly Weather Review 123, 383-400.

Segal, M., Avissar, R., McCumber, M.C. and Pielke, R.A. 1988: Evaluation of vegetation effects on the generation and modification of mesoscale circulations. Journal of the Atmospheric Sciences 45, 2268-92.

Segal, M., Schreiber, W.E., Kallos, G., Garratt, J.R., Rodi, A., Weaver, J. and Pielke, R.A. 1989: The impact of crop areas in northeast Colorado on midsummer mesoscale thermal circulations. Monthly Weather Review 117, 809-25.

Sellers, P.J., Mintz, Y., Sud, Y.C. and Dalcher, A. 1986: Simple biosphere model $(\mathrm{SiB})$ for use within general circulation models. Journal of the Atmospheric Sciences 43, 505-31.

Smith, E.A., Wai, M.M.-K., Cooper, H.J. and Rubes, M.T. 1994: Linking boundary-layer circulations and surface processes during FIFE 89. Part I: observational analysis. Journal of the Atmospheric Sciences 51, 1497-529.

Souza, E.P., Rennó, N.O. and Silva Dias, M.A.F. 2000: Convective circulations induced by surface heterogeneities. Journal of the Atmospheric Sciences 57, 2915-22.

Stidd, C.K. 1967: Local moisture and precipitation. Preprint Series No. 45, Desert Research Institute, University of Nevada, 34 pp. 
- 1975: Irrigation increases rainfall? Science 188, 279-81.

Sud, Y.C., Mocko, D.M. and Walker, G.K. 2001: Influence of land surface fluxes on precipitation: inferences from simulations forced with four ARM-CART SCM datasets. Journal of Climate 14, 3666-91.

Sun, W.Y. and Ogura, Y. 1979: Boundary-layer forcing as a possible trigger to a squall-line formation. Journal of the Atmospheric Sciences 36, 235-54.

Taylor, C.M. and Lebel, T. 1998: Observational evidence of persistent convective-scale rainfall patterns. Monthly Weather Review 126, 1597-607.

Taylor, C.M., Lambin, E.F., Stephenne, N., Harding, R.J. and Essery, R.L.H. 2002: The influence of land use change on climate in the Sahel. Journal of Climate 15, 3615-29.

Taylor, C.M., Saï, F. and Lebel, T. 1997: Interactions between the land surface and mesoscale rainfall variability during HAPEX-Sahel. Monthly Weather Review 125, 2211-27.

Trenberth, K.E. 1999: Atmospheric moisture recycling: role of advection and local evaporation. Journal of Climate 12, 1368-81.

Trenberth, K.E. and Guillemot, C.J. 1996: Physical processes involved in the 1988 drought and 1993 floods in North America. Journal of Climate 9, 1288-98.

Turner, C.L., Seastedt, T.R., Dyer, M.I., Kittel, T.G.F. and Schimel, D.S. 1992: Effects of management and topography on the radiometric response of a tallgrass prairie. Journal of Geophysical Research 97(D17), 18, 855-66.

Voronstov, P.A. 1963: Local air circulations in regions with ameliorated climate. In Dzerdzeevskii, B.L., editor, Sukhoveis and drought control, Jerusalem: Israel Program for Scientific Translations, 287-94.

Wai, M.M.-K. and Smith, E.A. 1998: Linking boundary layer circulations and surface processes during FIFE 89. Part II: maintenance of secondary circulations. Journal of the Atmospheric Sciences 55, 1260-76.

Walter-Shea, E.A., Blad, B.L., Hays, C.J., Mesarch, M.A., Deering, D.W. and Middleton, E.M. 1992: Biophysical properties affecting vegetative canopy reflectance and absorbed photosynthetically active radiation at the FIFE site. Journal of Geophysical Research 97(D17), 18, 925-34.
Walthall, C.L. and Middleton, E.M. 1992: Assessing spatial and seasonal variations in grasslands with spectral reflectances from a helicopter platform. Journal of Geophysical Research 97(D17), 18,905-12.

Wetzel, P.J. and Woodward, R.H. 1987: Soil moisture estimation using GOES-VISSR infrared data: a case study with simple statistical method. Journal of Climate and Applied Meteorology 26, 107-17.

Woodcock, D.W. 1992: The rain on the plain: are there vegetation-climate feedbacks? Global Planetary Change 5, 191-202.

Xie, P. and Arkin, P.A. 1997: Global precipitation: a 17year monthly analysis based on gauge observations, satellite estimates, and numerical model outputs. Bulletin of the American Meteorological Society 78, 2539-58.

Xue, Y., Sellers, P.J., Kinter, J.L. and Shukla, J. 1991: A simplified biosphere model for global climate studies. Journal of Climate 4, 345-64.

Yan, H. and Anthes, R.A. 1988: The effect of variations in surface moisture on mesoscale circulation. Monthly Weather Review 116, 192-208.

Yates, D.N., Chen, F, LeMone, M.A., Qualls, R., Oncley, S.P., Grossman, R.L. and Brandes, E.A. 2001: A Cooperative Atmosphere-Surface Exchange Study (CASES) dataset for analyzing and parameterizing the effects of land surface heterogeneity on area-averaged surface heat fluxes. Journal of Applied Meteorology 40, 921-37.

Yi, C., Davis, K.J., Berger, B.W. and Bakwin, P.S. 2001: Long-term observations of the dynamics of the continental planetary boundary layer. Journal of the Atmospheric Sciences 58, 1288-99.

Zangvil, A., Portis, D.H. and Lamb, P.J. 2004: Investigation of the large-scale atmospheric moisture field over the midwestern United States in relation to summer precipitation. Part II: recycling of local evapotranspiration and association with soil moisture and crop yields. Journal of Climate 17, 3283-301.

Zhang, D. and Anthes, R.A. 1982: A high-resolution model of the planetary boundary layer - sensitivity tests and comparisons with SESAME-79 data. Journal of Applied Meteorology 21, 1594-609. 